\title{
Análise da Expressão de MMP-2, -9, -14, TIMP-1,-2 e RECK em Granulomas e Cistos Periapicais
}

\section{Everdan Carneiro}

Tese apresentada à Faculdade de Odontologia de Bauru, da Universidade de São Paulo, como parte dos requisitos para obtenção do título de Doutor em Odontologia, na área de Endodontia.

Orientador: Prof. Dr. Roberto Brandão Garcia 


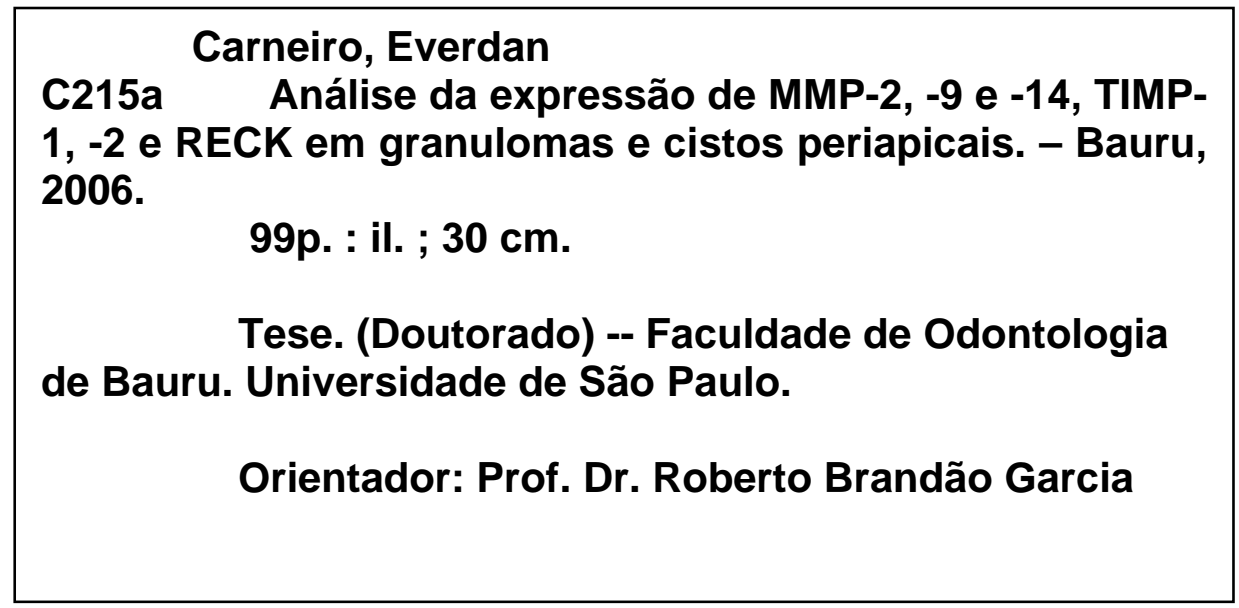

Data de aprovação pelo comitê de Ética em pesquisa da FOB: 05 de outubro de 2005.

A cópia do parecer de aprovação encontra-se no capítulo "Apêndice"

Autorizo, exclusivamente para fins acadêmicos e científicos, a reprodução total ou parcial desta dissertação/tese, por processos fotocopiadores e outros meios eletrônicos.

Assinatura: 


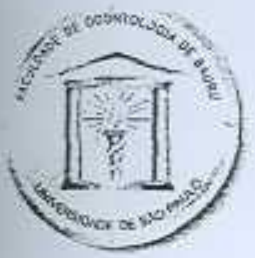

\section{Universidade de São Paulo Faculdade de Odontologia de Bauru}

Al. Dr. Octávio Pinheiro Brisolla, 9-75-Bauru-SP - CEP 17012-101 - C.P. 73 PABX (OXX14)235-8000-FAX (OXX14)223-4679

\section{Pós-Građuação}

e-mail: posgrad@fob.usp.br -Fone: (0XX14)235-8223

\section{FOLHA DE APROVAÇÃO}

Tese apresentada e defendida por

EVERDAN CARNEIRO

e aprovada pela Comissão Julgadora

em 10 de fevereiro de 2006.

\section{Mores Alis vants}

Prof. Dr. MARCO ANTONIO HUNGARO DUARTE

Universidade do Sagrado Coração - USC

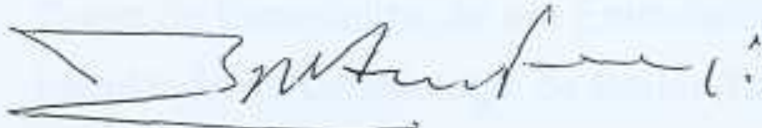

Prof. Dr. FRANCISCO JOSÉ DE SOUZA FILHO

Faculdade de Odontologia de Piracicaba - UNICAMP

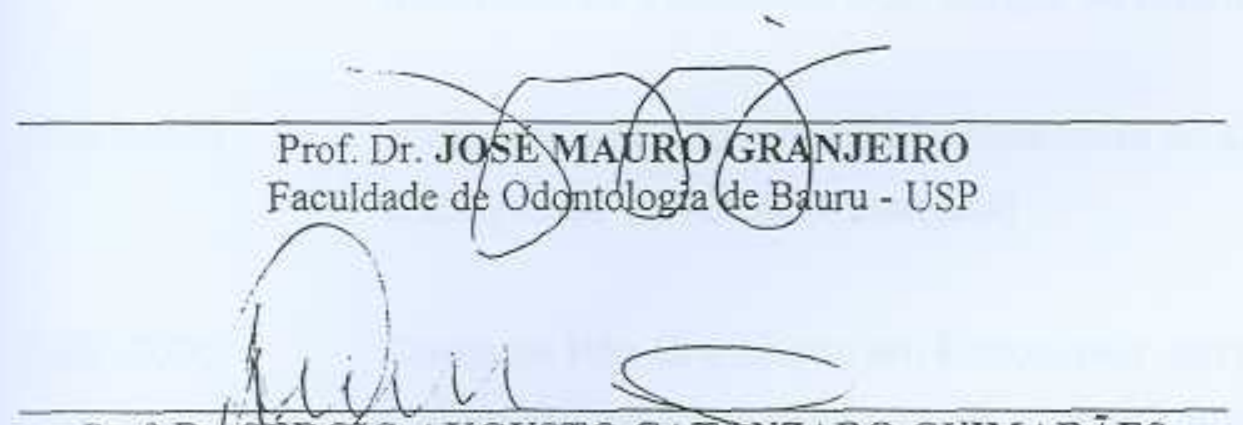

Prof. Dr(SERGIO AUGUSTO CATANZARO GUIMARÃES

Faculdade de Odontologia de Bauru- OSP

Prof. Dr. ROBERTJ BRAND́̃̃ GARCIA

Presidente dabanca e Orientador-USP

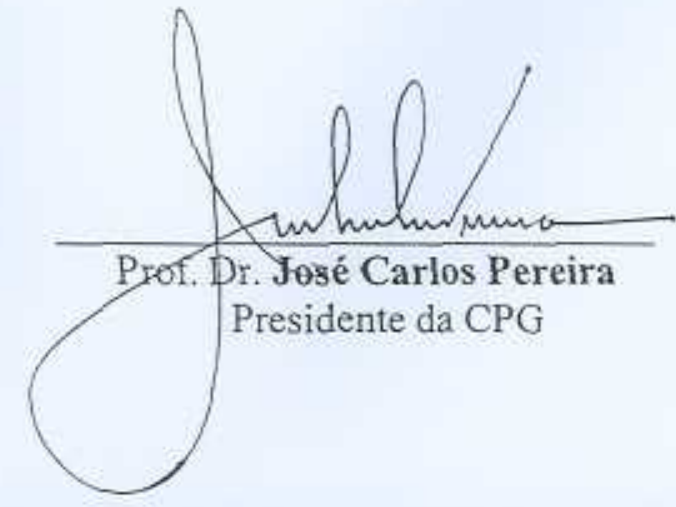




\section{EVERDAN CARNEIRO}

20 de abril de $1976 \quad$ Nascimento

Caçador - SC

Filiação

Fermiano Paes Carneiro Júnior

Rita Maria Pelegrinello Carneiro

1994-1998

Curso de Odontologia

Pontifícia universidade Católica do Paraná (PUC-PR)

$1999-2000$

Curso de Especialização em Endodontia

Faculdade de Odontologia de Bauru (USP)

2001-2003

Curso de Pós-Graduação em Endodontia, em nível de Mestrado, na Faculdade Odontologia de Bauru (USP)

2003- 2006

Professor de Endodontia da Universidade do Oeste Catarinense (UNOESC - Joaçaba)

2003-2006

Curso de Pós-Graduação em Endodontia, em nível de Doutorado, na Faculdade Odontologia de Bauru (USP)

Associações $\quad$ IADR - International Association for Dental Research SBPqO - Sociedade Brasileira de Pesquisa Odontológica ABO - Associação Brasileira de Odontologia 


\title{
Dedicatória
}

\section{A Deus}

Sempre presente em minha vida iluminando meus caminhos.

\begin{abstract}
À Maria Amélia Busato
Por se deixar viver dentro de mim...

Pela sabedoria em dosar paciência, bom humor, ânimo e incentivo.

Obrigado por criticar, dividir e me amar tanto!
\end{abstract}

\section{Aos meus pais Fermiano e Rita}

Pelo imenso amor, afeto e compreensão...

Obrigado pelo exemplo de vida e pelos ensinamentos que vão além dos livros...

\section{Ao meu irmão Gonçalo}

Pela amizade ímpar e companheirismo.

Obrigado pelo apoio pessoal e profissional.

\footnotetext{
À minha irmã Taciana (in memorian)

Pelo curto tempo que passamos juntos...

Pude compreender na sua ausência, quando ainda pequeno, que algumas coisas na vida são inestimáveis...

Saudades...
} 


\section{Agradecimentos}

Ao professor Dr. Roberto Brandão Garcia, pela valiosa e competente orientação. Pelo exemplo sereno de como conduz as situações; o que certamente propiciou meu crescimento científico, profissional e pessoal. Foram cinco anos de convívio... Certamente sempre será meu referencial de sabedoria, honestidade e busca incansável pelo conhecimento.

Muito Obrigado 


\section{Agradecimentos}

\section{Ao Prof. Dr. Ivaldo Gomes de Moraes}

Pelo constante incentivo desde a especialização. Um exemplo de ser humano que desenvolveu a capacidade de ouvir... Agradeço de coração pela oportunidade de conhecê-lo e toda amizade e carinho que sempre me dedicou.

Obrigado pelo "mel", alimento muitas vezes necessário que propiciou forças para continuar...

\section{Ao Professor Dr. José Mauro Granjeiro}

Exemplo de sinceridade e competência. Fonte inesgotável de perguntas e amor pela pesquisa. Obrigado pelo convívio enriquecedor e carinho que sempre demonstrou.

\section{À Professora Vânia Portela Dietzel Westphalen}

Por ser responsável pelo meu interesse e amor à Endodontia. Pessoa notável que colaborou decisivamente em minha formação.

Obrigado pela confiança em $\mathrm{mim}$ depositada, pela integridade e honestidade demonstradas em todos esses anos de amizade, meu eterno agradecimento e consideração.

\section{Aos Professores Clóvis Monteiro Bramante e Norberti Bernardineli}

Agradeço a oportunidade, apoio e confiança em mim depositada desde o início de minha atividade clínica e especialmente docente. Obrigado pelos ensinamentos e experiências transmitidas.

\section{À Professora Dra.Vanessa Lara}

Obrigado por me ensinar que sempre precisamos de um plano B. Admiro muito a sua maneira de orientar, equilibrando disciplina e descontração para executar as atividades.

\section{À Professora Dra.Maire Sogayar}

Pelo seu jeito cativante de ser, confiando a oportunidade de realizar 0 Real time RT-PCR no seu laboratório. 


\section{Ao Professor Dr. Gustavo Garlet}

Obrigado pela orientação e dedicação dispensada, não medindo esforços para contribuir com o trabalho e discutir minhas dúvidas.

Aos meus amigos, verdadeiros irmãos:

\section{Renato}

Obrigado pela amizade e companheirismo, sempre presentes, que permanecerão pelo resto de minha vida... Você sabe o quanto foi essencial para realização deste trabalho, muitas vezes me orientando. Admiro muito sua inteligência e capacidade incansável de questionar.

\section{Ulisses}

Obrigado por ser meu espelho profissional. Você sabe que sempre procurei ser um pouco "Ulisses" (monitor, especialista, mestre e doutor). Agradeço de coração todo carinho sempre dispensado.

\section{Fábio}

Obrigado pelo convívio, companheirismo, ensinamentos e momentos de descontração compartilhados.

\section{À amiga-irmã Fernanda}

Pela amizade fiel e sincera. Tenho certeza que não nos encontramos por acaso nesta jornada. Saiba que te admiro muito.

Aos meus amigos e colegas de Doutorado Silvana, Graziela, Viviane, Giovana e Rogério, pelo convívio agradável e troca de ensinamentos.

\section{À Família Letra Menezes}

Pelo convívio sempre receptivo e pelas diárias de hotel. Agradeço especialmente a Ariadne pela amizade e ao Lucas por fazer parte desta etapa, possibilitando muita descontração. 


\section{À Família Gomes de Moraes}

Pelo carinho dispensado e por fazerem de sua casa, a minha. Obrigado pela atenção e sensibilidade.

Aos amigos Dani, Bruno e Tânia...

Que fizeram da Histo minha segunda casa.

\section{Aos meus amigos de Pós-graduação}

Rodrigo, Diego, Leonardo e Rosário pelo convívio sincero e divertido.

\section{À Rita Figueira}

Pela disposição e paciência, deixando seus compromissos para auxiliar a parte laboratorial deste trabalho.

Aos funcionários do Departamento de Endodontia: Sueli, D. Neide, Edimauro e Patrícia, pela consideração, colaboração e atenção sempre dispensadas.

\section{À Fatiminha}

Agradeço pela dedicação, amizade e carinho.

\section{À minha amiga Luci Binder}

Obrigado pela amizade fiel, essencial para meu crescimento profissional. 


\section{SUMÁRIO}

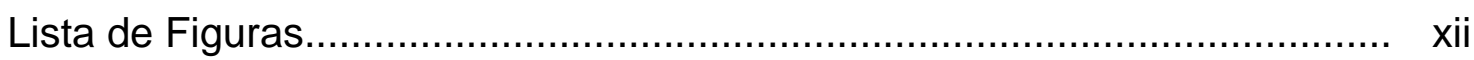

Lista de Abreviaturas e Símbolos...................................................... xiv

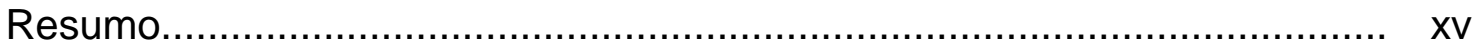

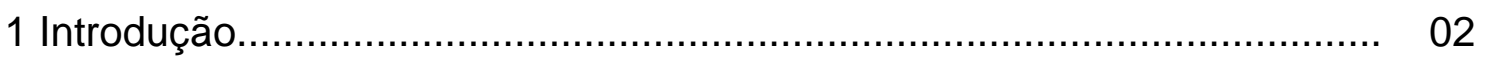

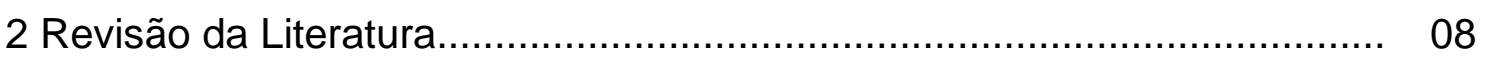

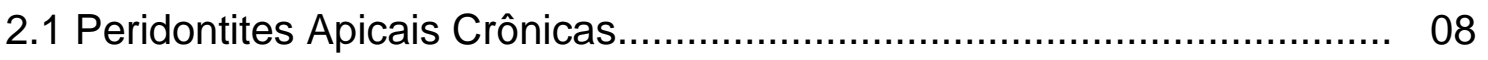

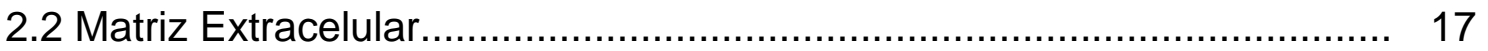

2.3 Metaloprotease da Matriz.................................................. 18

2.3.1 Estrutura e Função das MMPs.............................................. 20

2.3.2 Metaloprotease da matriz na Polpa e em Lesões Periapicais............. 24

2.4 Inibidores Teciduais de Metaloproteases (TIMPs)......................... 29

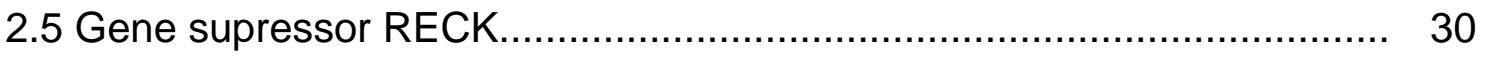

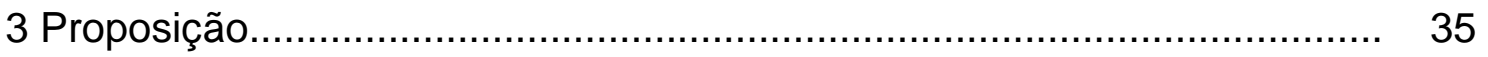

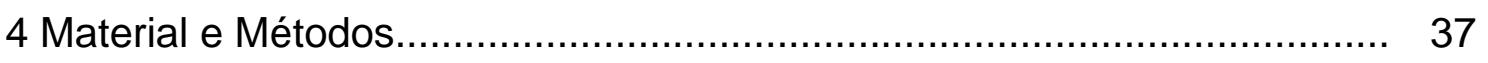

4.1 Amostras teciduais de lesões periapicais para RT-PCR ................... 37

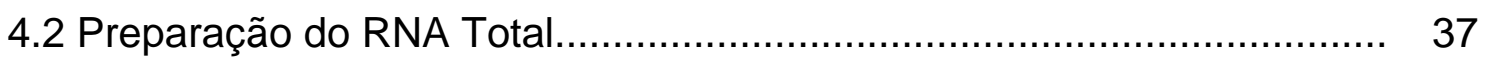

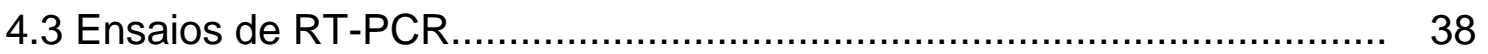

4.3.1 Síntese da primeira fita do cDNA....................................... 38

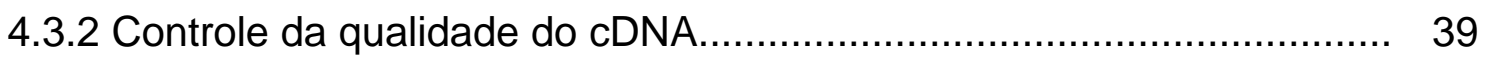

4.4 Confirmação dos genes por Real-Time PCR .............................. 39

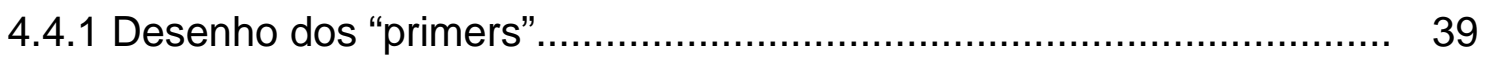

4.4.2 Confirmação da expressão diferencial............................................ 41 
4.4.3 Análise estatística.................................................................... 43

4.5 Amostras teciduais de lesões periapicais para imuno-histoquímica ....... 44

4.5.1 Controle positivo e negativo.......................................................... 46

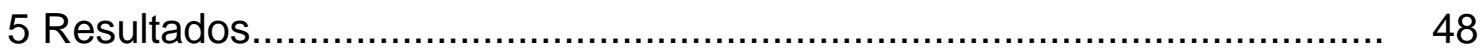

5.1 Expressão da matriz metaloprotease-2 em granulomas, cistos e cicatriz periapicais.

5.2 Expressão da matriz metaloprotease- 9 em granulomas, cistos e cicatriz periapicais

5.3 Expressão de RECK em granulomas, cistos e cicatriz periapicais.......... 50

5.4 Expressão de TIMP-1 em granulomas, cistos e cicatriz periapicais........ 51

5.5 Expressão de TIMP-2 em granulomas, cistos e cicatriz periapicais........ 52

5.6 Expressão da matriz metaloprotease-14 em granulomas, cistos e cicatriz periapicais

5.7 Correlação entre os níveis de transcritos para MMP-2, -9, -14, TIMP-1, -2 e RECK

5.8 Imunomarcação de MMP-2 e -9 para granulomas periapicais................. 58

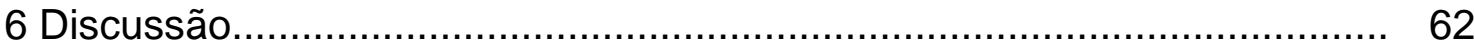

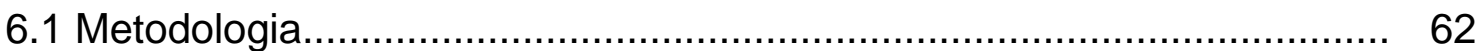

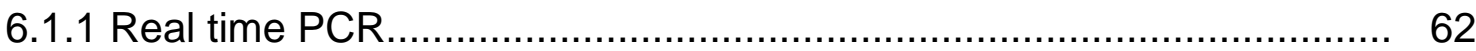

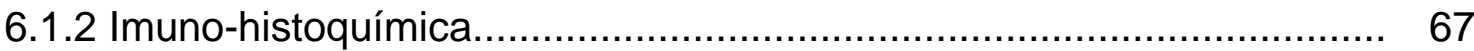

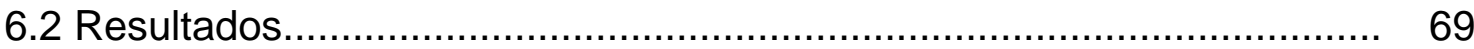

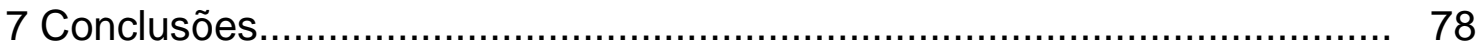

Referências Bibliográficas...................................................................... 80

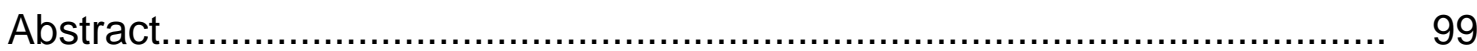


Apêndice 


\section{LISTA DE FIGURAS}

Figura 1 - Níveis médios de expressão das MMP-2 entre granulomas, cistos e cicatriz periapicais.

Figura 2 - Níveis médios de expressão das MMP-2 nos grupos das amostras (gráfico de dispersão)

Figura 3 - Níveis médios de expressão das MMP-9 entre granulomas, cistos e cicatriz periapicais.

Figura 4 - Níveis médios de expressão das MMP-2 nos grupos das amostras (gráfico de dispersão)

Figura 5 - Níveis médios de expressão de RECK entre granulomas, cistos e cicatriz periapicais.

Figura 6 - Níveis médios de expressão de RECK nos grupos das amostras (gráfico de dispersão)

Figura 7 - Níveis médios de expressão de TIMP-1 entre granulomas, cistos e cicatriz periapicais.

Figura 8 - Níveis médios de expressão das TIMP-1 nos grupos das amostras (gráfico de dispersão)

Figura 9 - Níveis médios de expressão de TIMP-2 entre granulomas, cistos e cicatriz periapicais.

Figura 10 - Níveis médios de expressão das TIMP-2 nos grupos das amostras (gráfico de dispersão).

Figura 11 - Níveis médios de expressão de MMP-14 entre granulomas, cistos e cicatriz periapicais. 
Figura 12 - Níveis médios de expressão das MMP-14 nos grupos das amostras (gráfico de dispersão) 54

Figura 13 - Correlações positivas e não significantes................................ 55

Figura 14 - Seqüência gráfica de correlações positivas............................... 56

Figura 15 - Seqüência gráfica de correlações não significantes.................. 57

Figura 16 - Imunomarcação para MMP-2 (A) 40X; (B) 100X...................... 58

Figura 16 - Imunomarcação para MMP-2 (C) 40X.................................... 59

Figura 17 - Imunomarcação para MMP-9 (D) 40X; (E, F) 100X; (G) 40X..... 59

Figura 18 - Imunomarcação para CD68+ (H) 40X; (B) 100X; (C) 40X.......... 60 


\section{LISTA DE ABREVIATURAS E SIMBOLOS}

$\begin{array}{ll}{ }^{\circ} \mathrm{C} & \text { Graus Celsius } \\ \text { 100X } & \text { Aumento de 100 vezes } \\ 40 X & \text { Aumento de quarenta vezes } \\ \text { CDNA } & \text { Ácido desoxirribonucléico complementar } \\ \text { CD68+ } & \text { imunohistoquimicamente positivo para o cluster de } \\ & \text { diferenciação sessenta e oito } \\ \text { DAB } & \text { Diaminobenzidina } \\ \text { ELISA } & \text { Ensaio imunoenzimático (Enzyme-linked immunosorbent } \\ & \text { Assay) } \\ \text { KDa } & \text { Quilodaltons } \\ \text { Ig } & \text { Imunoglobulina } \\ \text { IL } & \text { Interleucina (interlukin) } \\ \text { PBS } & \text { Solução salina tamponada com fosfato e magnésio } \\ \text { PBSA } & \text { PBS sem cálcio ou magnésio } \\ \text { PCR } & \text { Reação em cadeia da polimerase (polymerase chain reaction) } \\ \text { PGE2 } & \text { Prostaglandina E dois } \\ \text { PMN } & \text { Polimorfonucleares } \\ \text { PM } & \text { Peso molecular } \\ \text { pH } & \text { Potencial de hidrogênio } \\ \text { mM } & \text { Milimolar } \\ \text { MEC } & \text { Matriz extracelular } \\ \text { MMP } & \text { Metaloprotease de matriz } \\ & \end{array}$


RealTimePCR Reação em cadeia da polimerase quantitativa

RECK Reversão induzida por proteína rica em cisteína com Kazal motif (Reversion-inducing cysteine-rich protein with Kazal motifs)

RNAm Ácido Ribonucléico mensageiro

RT Transcrição reversa (reverse transcription)

SD Desvio padrão (Standart deviation)

TE

Solução tampão (10mM Tris-Cl pH 7,5 e 1 mM EDTA)

TGF- $\beta \quad$ Fator de crescimento Transformante $\beta$ (transforming growth factor $\beta$ )

TIMP Inibidor tecidual de metaloprotease ( tissue inhibitor of metalloptroteinase)

TNF

Fator de necrose tumoral (Tumor necrosis factor) 
A degradação de proteínas da matriz extracelular pelas metaloproteases da matriz (MMPs) ocorre nos processos fisiológicos (turnover) bem como nos processos patológicos (inflamação, neoplasias, etc). A atividade das MMPs nos tecidos é regulada, naturalmente, por um grupo de inibidores teciduais de metaloproteases (TIMPs). Recentemente, um novo inibidor de MMPs, chamado RECK (proteína indutora de reversão rica em cisteína com domínios Kazal) foi identificado. Neste estudo, verificamos os níveis de transcritos para metaloproteases da matriz (MMP-2, -9 e -14), inibidores teciduais de metaloproteases (TIMP-1 e -2) e RECK, por meio da técnica de Real-Time RT-PCR, assim como as células envolvidas em granulomas periapicais para MMP-2 e -9, por meio de marcações de imuno-histoquímica. As amostras deste estudo foram coletadas de cirurgias paraendodônticas, sendo 15 submetidas ao Real-Time RT PCR (8 granulomas periapicais, 6 cistos periapicais e 1 cicatriz apical), e 10 para imuno-histoquímica (10 granulomas periapicais). Os resultados para o Real-Time PCR demonstraram que houve a expressão de MMP-2, -9, -14, TIMP-1, -2, e RECK em granulomas e cistos periapicais, não havendo diferença estatisticamente significante entre as duas patologias periapicais frente aos genes testados. Todavia, quando o grupo lesão periapical (granuloma e cisto periapical) foi confrontado frente aos genes pesquisados, houve uma correlação significativa entre os níveis de transcritos para MMP-2, -9 e -14, TIMP-1, -2 e RECK. Para as imunomarcações nos granulomas periapicais, a MMP-2 apresentou um padrão mais difuso, dispondo-se perifericamente às células e dispersas pela MEC, em comparação com a MMP-9 que apresentou um padrão mais localizado e restrito. Os macrófagos foram às células que mais expressaram estas metaloproteases da matriz. 
INTRODUÇÃO 


\section{INTRODUÇÃO}

A infecção bacteriana na polpa dentária induz uma resposta inflamatória, que, não sendo tratada, determina a sua destruição e conseqüente contaminação do sistema de canais radiculares e túbulos dentinários, desencadeando, por sua vez, infecção no periodonto apical. A persistência desse evento provoca a migração, ativação e a interação coordenada de células imuno-competentes ${ }^{45}$, caracterizando a periodontite apical. Essa reação de defesa do periodonto apical frente à persistência dos agentes irritantes contidos no sistema de canais radiculares infectados provoca a cronificação da periodontite apical e com o decorrer do tempo, a reabsorção dos tecidos paraendodônticos apicais.

A estrutura histopatológica das periodontites apicais crônicas ou lesões inflamatórias periapicais crônicas compreende, a partir do forame apical, as zonas necrótica e exsudativa, granulomatosa e fibrosa infiltradas ${ }^{29,}{ }^{104}$, por células imunocompetentes em interação, como os leucócitos polimorfonucleares, macrófagos, linfócitos T, B e plasmócitos. Os tecidos granulomatoso e fibroso, representantes da atividade proliferativa da inflamação crônica, desenvolvem-se e ocupam o espaço deixado pelo osso reabsorvido. ${ }^{29,93}$

Nas lesões inflamatórias periapicais crônicas estão incluídos granulomas e cistos, sendo ambas as patologias que representam dois estágios de desenvolvimento de um mesmo processo inflamatório. Os fatores 
que determinam a transformação cística de alguns granulomas, bem como o mecanismo envolvido para sua formação, ainda são controversos. ${ }^{64}$

O conceito básico do tratamento do sistema de canais radiculares se baseia na remoção mecânica e química dos irritantes do interior de canais infectados, sua modelagem, sua obturação e selamento coronário, procurando bloquear a micro infiltração de fluidos, bactérias, propiciando o reparo de lesões periapicais. Entretanto, os mecanismos intrínsecos que mantêm a lesão periapical permanacem obscuros e as ferramentas de diagnóstico disponíveis não são capazes, ainda, de avaliar aqueles mecanismos, a progressão da periodontite apical crônica nem, tampouco, prever a sua futura exarcebação. ${ }^{93}$ Todavia, parece que o interesse maior está fundamentado em conhecer a progressão ou expansão das periodontites apicais crônicas, aplicando para isso, conceitos microbiológicos, patológicos, imunológicos e de biologia molecular.

As interações celulares com a matriz extracelular são essenciais para um normal desenvolvimento e funcionabilidade do organismo humano. A modulação destas interações entre célula e matriz ocorre por meio da ação de um único sistema proteolítico, responsável pela hidrólise de uma variedade de componentes da matriz extracelular. Para a manutenção da integridade e composição da estrutura da matriz, aquele sistema enzimático tem um papel principal no controle de sinais licitados pelas moléculas da matriz, regulando a proliferação, diferenciação e morte celular. A renovação e remodelação da matriz extracelular (MEC) devem ser altamente reguladas. A proteólise 
descontrolada contribui para um desenvolvimento anormal e geração de muitas condições patológicas. ${ }^{46}$

O colágeno é a principal proteína destruída durante o desenvolvimento das lesões periapicais, determinando a degradação dos feixes de fibras colágenas que ligam os dentes ao osso circundante. ${ }^{93}$ A degradação colagênica se dá por um grande grupo de enzimas, conhecidas por metaloproteases da matriz (MMPs), que regulam o equilíbrio entre célula e matriz. As MMPs são endopeptidases zinco dependentes, conhecidas por suas habilidades de clivar um ou muitos constituintes da matriz extracelular, bem como proteínas não pertencentes a mesma. Elas compreendem uma ampla família de proteases que dividem elementos estruturais e funcionais comuns. ${ }^{9}$, $30,46,56,82,98$

A degradação de proteínas da matriz extracelular pelas MMPs ocorre na sua renovação (turnover) e nos processos inflamatórios. Essa degradação requer a atividade de muitas endopeptidases diferentes, de acordo com o substrato. Essas enzimas estão em baixo nível em tecidos normais e aumentadas durante a inflamação. ${ }^{98,77}$. As endopeptidases são produzidas por células residentes no tecido conjuntivo em resposta aos estímulos bacterianos e às citocinas. Por outro lado, várias proteinases são produzidas, também, por células inflamatórias, como as colagenases (MMP-1 e/ou MMP-8), elastase e gelatinase (MMP-2 e/ou MMP-9), as quais irão promover a desnaturação do colágeno ou gelatina da matriz extracelular. ${ }^{46,56} \mathrm{Na}$ inflamação, as MMPs-9 são principalmente secretadas por leucócitos polimorfonucleares neutrófilos (PMNs) e macrófagos. ${ }^{98}$ 
Ampla evidência existe no papel das MMPs nos processos fisiológico e fisiopatológico das interações entre célula e matriz extracelular,incluindo embriogênese, reparo, inflamação, artrite e câncer. A associação de MMPs com metástase de câncer tem seu interesse aumentado consideravelmente porque estas proteases representam um alvo atrativo para o desenvolvimento de novos medicamentos antimetastáticos, que objetivam a atividade inibitória de MMP.

A atividade das MMPs nos tecidos é regulada, naturalmente, por um grupo de inibidores teciduais de metaloproteinases (TIMPs). Um desequilíbrio entre produção de MMPs e TIMPs pode permitir a destruiçao tecidual. ${ }^{43,} 90$ Recentemente, um novo inibidor de MMPs, chamado RECK (proteína indutora de reversão rica em cisteína com domínios Kazal) foi identificado. RECK é uma glicoproteína de ancoragem em membranas celulares, cuja estrutura é diferente das TIMPs, expressada em vários tecidos normais, mas não identificada em células derivadas de tumores. A RECK inibe MMPs-9, -2 e -14, funcionando também, como um regulador estrutural de processo de renovação (turnover) da matriz extracelular. ${ }^{82}$ A RECK inibe a MMP-9 de dois modos: supressão da sua secreção e direta inibição de sua atividade enzimática. ${ }^{92}$

Nos últimos anos, as MMPs têm sido alvo de atenção em endodontia, ${ }^{18,}$ $30,42,56,64,77,98,99$, devido à suas atividades de degradação da matriz extracelular nos processos inflamatórios. A expressão de MMPs nas células inflamatórias ${ }^{72}$ em granulomas e cistos periapicais ${ }^{77}$ tem sido pesquisada, objetivando conhecer melhor o mecanismo de formação e expansão daquelas lesões. 
Sabendo que a glicoproteina RECK inibe a atividade das MMPs -2 , -9 , e -14 e que metaloproteases da matriz e seus inibidores estão presentes em lesões periapicais, se torna válido um estudo que verifique os níveis de transcritos por meio da técnica da transcrição reversa pela reação em cadeia da polimerase (Real Time RT-PCR), assim como identificar as células que expressam MMP-2 e -9 em granulomas periapicais, por meio de marcações de imuno-histoquímica. 
REVISÃO DE LITERATURA 


\section{REVISÃO DA LITERATURA}

A revisão da literatura será dividida nos seguintes tópicos: Periodontites apicais crônicas com ênfase em granuloma apical e cisto periodontal apical, matriz extracelular, metaloprotease da matriz, inibidores teciduais de mataloproteases (TIMPs) e RECK.

\subsection{Periodontites Apicais Crônicas}

As periodontites apicais crônicas ou simplesmente lesões inflamatórias periapicais crônicas são respostas inflamatórias a agentes microbianos do sistema de canais radiculares ${ }^{41,50,88}$. Estas lesões, conforme os tipos celulares inflamatórios presentes, mostram a participação concomitante das reações inflamatórias não específicas e a de especificidade imunológica. ${ }^{66,108}$

A infecção da cavidade pulpar resulta na contaminação dos tecidos periapicais ocorrendo, desse modo, à colonização bacteriana e, consequentemente a reação inflamatória e degradação da estrutura tecidual do periápice ${ }^{93}$. Essa reação inflamatória ou periodontite apical desencadeia uma reação imune contra a proliferação bacteriana, gerando numerosos mediadores inflamatórios de uma variedade de células, visando à destruição dos patógenos invasores. Esse mecanismo imunopatológico envolve as reações de hipersensibilidade, podendo ser mediada por anticorpos (hipersensibilidade 
humoral) ou por células (hipersensibilidade celular). Ainda por analogia às reações imunes de proteção, a resposta humoral é conhecida por hipersensibilidade imediata e a celular por hipersensiblidade tardia. ${ }^{29}$

$\mathrm{Na}$ formação, desenvolvimento e perpetuação da periodontite apical, a cooperação entre subpopulações funcional e fenotipicamente diferentes de macrófagos e linfócitos $\mathrm{T}$, resultam em um balanço equilibrado de processos de proteção e de destruição tecidual. Devido ao fluxo contínuo de microrganismos e seus produtos, do sistema de canais radiculares infectados, a lesão periapical não é autolimitante, apesar do poderoso mecanismo de defesa montado pelo sistema imunoinflamatório do hospedeiro. Portanto, a efetiva desinfecção do sistema de canais radiculares é essencial para que o reparo possa ocorrer. ${ }^{14}$, 63

MÁRTON; KISS ${ }^{45}$, em 2000, descrevem em uma revisão sobre reações imunes em periodontites apicais, enfatizando que, apesar das reações do organismo frente aos agentes bacterianos possuírem caráter defensivo, a destruição de componentes do tecido periapical é inevitável, resultando, inclusive na reabsorção óssea. O entendimento do equilíbrio dinâmico entre mecanismo defensivo e destrutivo pode fornecer bases para melhor entendimento de sinais e sintomas das periodontites apicais crônicas, influenciando nas estratégias de tratamento.

A histopatologia de lesões periapicais crônicas representa uma estrutura de defesa e uma de manutenção altamente organizada, ou seja, as contínuas produção e difusão de antígenos para o periodonto apical em hospedeiro 
sensível induzem, ao lado das reações imunitárias de proteção, reações que causam danos aos tecidos locais. ${ }^{29}$

O aspecto microscópico de um típico granuloma periapical demonstra uma estrutura, a partir do forame apical, formada pelas zonas necrótica, exsudativa, granulomatosa e fibrosa ${ }^{45} \mathrm{e}$, de acordo com as zonas de predominância, as lesões podem ser classificadas como exsudativas, granulomatosas, granulofibróticas e fibrosadas. ${ }^{104}$ Lesões exsudativas são caracterizadas pela necrose extensa e exsudação com edema intersticial, correspondendo às lesões incipientes agudas ou aos períodos de exacerbação aguda das periodontites periapicais crônicas.

As células inflamatórias que compõem basicamente uma lesão periapical são: leucócitos polimorfornucleares neutrófilos, linfócitos $T$ e $B$, plasmócitos e macrófagos, além de componentes quimiotáticos presentes na região apical e as imunoglobulinas ${ }^{29,44}$. Em áreas de necrose e de exsudação em infecções periradiculares, os leucócitos polimorfonucleares neutrófilos representam a primeira linha de defesa contra invasão bacteriana oriunda de canais radiculares infectados. Devido a sua função de fagocitose e de promover a morte bacteriana, essas células destroem e eliminam a maioridade dos microrganismos, prevenindo a expansão da lesão. Os neutrófilos estão presentes, também, na zona granulomatosa de uma lesão periapical, de permeio aos linfócitos, plasmócitos, eosinófilos e elementos fibrovasculares. A sua presença de fato é menos notada em zonas granulomatosas, porque a infecção microbiana nesta zona é menor, contudo sua função antimicrobiana persiste, contribuindo para resistir à invasão bacteriana, bem como ao ingresso 
de partículas de membranas patogênicas, antígenos, toxinas e enzimas, provenientes dos canais radiculares e de zonas exsudativas. ${ }^{65}$

Eosinófilos são encontrados na zona granulomatosa das periodontites apicais crônicas, representando a menor população do infiltrado de leucócitos polimorfonucleares. ${ }^{29,45,107}$

As imunoglobulinas (lg) estão presentes nas periodontites apicais crônicas participando da reação de hipersensibilidade imediata, além do envolvimento em processos infecciosos exsudativos agudos. 48 Imunoglobulinas do tipo $\lg G$, IgM, IgA e $\lg E$ acompanhadas de fragmentos do complemento são observadas em lesões periapicais em diversos estudos ${ }^{38,51,}$ 52, 94 As $\lg G$ e $\operatorname{lgA}$ são percebidas em alta concentração em granulomas periapicais, nas paredes e fluídos císticos ${ }^{35}$. Os linfócitos $B$ e suas progênitas, os plasmócitos, que produzem $\lg G$, $\lg A$, IgM são evidenciados em tecidos granulomatosos periapicais humanos e em modelos experimentais em animais. 83106 Estudos de imuno-histoquímica e quantificação de imunoglobulinas, por métodos de imunoensaio, confirmaram a produção local destas por meio dos níveis de RNA mensageiro (RNAm). ${ }^{94}$

Comparando as populações de linfócitos B e T, as periodontites apicais crônicas demonstram um excesso de células $T$ sobre os linfócitos $B$, visto tanto em humanos como em lesões periapicais induzidas em ratos. 1, 34, 62 Este dado, aliado à presença constante de macrófagos, confirma a predominância da reação de hipersensibilidade tardia no mecanismo de formação das lesões inflamatórias crônicas. ${ }^{29}$ 
Linfócitos $\mathrm{T}$ e $\mathrm{B}$ predominam em lesões periapicais e tem papel importante na resposta imune antígeno-específica. ${ }^{107}$ A proporção de Linfócitos T é maior que a de Linfócitos B nas lesões periapicais e a proporção entre linfócitos-supressores/citotóxicos (LT-8) e os linfócitos-auxiliares (LT-4) tem importância durante a fase de progressão das lesões. ${ }^{6,23,80}$ Os LT - 8 participam ativamente no processo de estabilização das lesões periapicais inflamatórias, e os LT-4 têm participação na fase inicial ou destrutiva das lesões. ${ }^{37}, 44,65$ Isso sugere o porquê LT-8 são encontrados em maior concentração que os LT-4 nos cistos em relação aos granulomas apicais. ${ }^{72}$

Os macrófagos, em concomitância com os linfócitos, desenvolvem nas periodontites apicais crônicas, ações de defesa e de desenvolvimento da lesão, sendo recrutados por múltiplos fatores quimiotáticos. Nos processos infecciosos com predominância de macrófagos, independente de sua localização, há a caracterização do autêntico granuloma, um exemplo é na hanseníase e na tuberculose. Nestas patologias não há destruição total dos agentes infecciosos, estes permanecem em parasitismo no interior dos macrófagos, determinando a continuidade dos granulomas. A persistência e interação dos microrganismos com os macrófagos estimula sua atividade secretora, resultando em liberação de enzimas hidrolíticas com destruição local dos tecidos. A destruição tecidual, associada ao mecanismo imunológico que mobiliza e ativa os macrófagos, constitui os elementos mais importantes do mecanismo formador dos granulomas infecciosos. A cronicidade dos granulomas infecciosos representa, portanto, um estado de imunodeficiência, 
pois, neste caso, os linfócitos $\mathrm{T}$ sensíveis, não ativam suficientemente os macrófagos para induzir a destruição do agente infeccioso. ${ }^{29}$

A periodontite apical crônica ou lesão inflamatória periapical crônica, denominada também de granuloma periapical, não tem a composição celular predominantemente macrofágica e sendo assim, histopatologicamente, não se trata de um autêntico granuloma. Todavia tal denominação ficou consagrada na Odontologia. $\mathrm{Na}$ formação do granuloma periapical, representado principalmente por macrófagos, linfócitos e plasmócitos, estão envolvidos fenômenos imunopatológicos, especialmente relacionados à hipersensibilidade celular; isto ocorre quando o agente indutor tem poder imunogênico. $\mathrm{Na}$ ausência desta condição, o granuloma é dito do tipo corpo estranho, fato observado no extravasamento de alguns cimentos, pastas obturadoras e gutapercha. ${ }^{21,55}$

A periodontite apical crônica instalada pode evoluir gradativamente à custa da proliferação fibro-angioblástica e acúmulo de células inflamatórias na área periodontal em torno do forame apical, determinando, ao longo do tempo, reabsorção óssea, cementária e dentinária nos períodos mais prolongados. No interstício da lesão periapical, há infiltração de polimorfonucleares neutrófilos e pequenos focos de destruição tecidual, como resultado do primeiro contato com as bactérias e seus produtos. A partir desta região, as bactérias e seus produtos, que vencem esta barreira, serão reconhecidos pelos linfócitos e digeridos pelos macrófagos. ${ }^{19,98}$

No granuloma periapical (periodontite apical crônica granulomatosa), tem-se como principal elemento caracterizador a presença de eventos 
morfológicos e imunopatológicos de uma lesão inflamatória crônica granulomatosa, de longa duração, com caráter predominantemente proliferativo e induzido por agentes agressores de origem bacteriana advindos do canal radicular. Sua finalidade está relacionada com a localização e delimitação dos agentes agressores aos limites do periápice, revelando a persistência do agente agressor no local, provocando a ocorrência de fenômenos imunopatológicos específicos importantes na manutenção da periodontite apical crônica como a presença constante de células imunocompetentes, de imunoglobulinas, de componentes do complemento, bem como inúmeros outros mediadores químicos, incluindo as várias citocinas e fatores de crescimento. ${ }^{45}$

O granuloma periapical pode demonstrar na sua estrutura:

a) Cordões e ilhotas de células epiteliais, proliferantes ou não, originadas dos restos epiteliais de Malassez;

b) Células espumosas ou pseudoxantomatosas, representadas pelos macrófagos carregados de lipídios decorrentes da liberação constante de células mortas;

c) Corpúsculo hialino de Russel, representados por formações eosinofílicas esféricas isoladas ou em forma de aglomerados, correspondentes aos plasmócitos com perda da capacidade secretória de proteínas imunoglobulinas;

d) Cristais de colesterol, parte dos lipídios liberados em decorrência da morte celular não difusível e nem fagocitada, cristaliza-se no espaço intercelular. 
Clinicamente, o granuloma apical é quase sempre assintomático. O paciente pode, ocasionalmente, fornecer uma história de dor que, mais tarde, diminui ou desapareceu. A radiografia, na fase inicial da sua formação, poderá mostrar um espessamento pronunciado do pericemento apical e à medida que a periodontite apical crônica evolui, pela neoformação tecidual e conseqüente reabsorção do osso, aparece com uma área radiolúcida, de forma circular ou ovóide, estendendo-se apicalmente. ${ }^{21}$

A origem do cisto periodontal apical (periodontite apical cística) está no granuloma apical, a partir de seu componente epitelial derivado dos restos epiteliais de Malassez. Esses restos são estimulados pela reação inflamatória periapical instalada, entram em proliferação, invadindo a estrutura do granuloma periapical, aumentando, gradativamente, a massa de tecido epitelial 29 e formando, concomitantemente, a micro cavitação cística, cujo mecanismo está fundamentado em várias teorias. ${ }^{45,64}$

As condições indutoras para provocar a proliferação epitelial dependem da diminuição da tensão de oxigênio, aumento da tensão de gás carbônico, associados a uma redução do $\mathrm{pH}$. Estabelecida à fase de iniciação da cavitação cística, os cistos periodontais apicais apresentam crescimento contínuo e lento, provocado pela pressão hidrostática intra-cavitária, que se enriquece de líquido gradativamente à custa da pressão oncótica do líquido cístico. ${ }^{29}$

Enfocando aspectos microscópicos e imunohistoquímicos do cisto periodontal apical ROCHA ${ }^{71}$ em 1991, descreveu que o epitélio de revestimento da cavidade cística não se apresenta contínuo na maioria dos casos, existindo 
áreas de interrupção onde se encontra infiltrado inflamatório composto, predominantemente, por linfócitos T e macrófagos em grande quantidade, denotando um provável reconhecimento antigênico do epitélio cístico, o qual na sua grande maioria apresenta-se estratificado pavimentoso, não queratinizado. As camadas superficiais, desse epitélio, geralmente estão desorganizadas e ausentes, determinando irregularidades na sua superfície. De permeio às células epiteliais, geralmente há exuberante infiltração de leucócitos polimorfonucleares neutrófilos, caracterizando a exocitose neutrofílica. Subjacente ao epitélio de revestimento o infiltrado inflamatório crônico é bem definido e composto por macrófagos e linfócitos, do tipo T e B, sendo que estes estão localizados mais difusamente na parede cística.

$\mathrm{Na}$ parede do cisto periodontal apical podem ser encontradas áreas típicas do granuloma apical antecedente, especialmente quando a transformação cística foi recente. Nos cistos maiores e mais velhos, a parede cística é fibrosa, densa e colagenizada, apresentando-se com graus variáveis de infiltração inflamatória mononuclear, ora focal ou difusa. A distribuição dos linfócitos T e dos macrófagos denota uma íntima relação com a presença do epitélio cístico de revestimento; sua localização, concentração e migração parecem estar relacionadas para a destruição daquele tecido de revestimento. 29

A presença de cristais de colesterol constitui um dos achados mais comuns no cisto peridontal apical. Sua localização é variável, podendo ocupar grande parte do lume e da parede cística. O conteúdo cístico revela-se, ainda, constituído por material amorfo, possivelmente pelo alto teor protéico, presença 
marcante de células pseudoxantomatosas, leucócitos mononucleares e polimorfonucleares, hemáceas, células epiteliais descamadas. ${ }^{5,29}$

A terapêutica endodôntica só consegue ser amplamente discutida quando os princípios biológicos são conhecidos, contudo, as ferramentas diagnósticas conhecidas são ainda incapazes de precisar a progressão das periodontites apicais, nem tampouco, prever sua futura exacerbação. Baseado nisso, a imunopatologia envolvendo as conseqüências da necrose pulpar deve ser constantemente estudada.

\subsection{Matriz extracelular}

A matriz extracelular (MEC) é definida como uma rede complexa de componentes protéicos, proteoglicanos e glicoproteínas secretados, que circundam os fibroblastos, unindo as células e mantendo a estrututra tridimensional do corpo. A MEC proporciona, portanto, suporte mecânico para as células e integridade estrutural para os tecidos. ${ }^{22,33,67}$

A MEC compreende uma rede dinâmica de macromoléculas interativas como colágenos, proteínas não colagênicas, fibras elásticas e proteoglicanos. 69 Tradicionalmente era vista como um substrato estável para as células e como determinante da arquitetura tecidual, no entanto mais funções foram conhecidas, como a de papel instrutivo, provendo informações estruturais para integrinas e outras moléculas da superfície celular, servindo assim de 
reservatório para fatores de crescimento. ${ }^{2}$ Desta forma, os componentes da matriz modulam o comportamento celular, criando ambientes celulares influentes. A renovação (turnover) da MEC é parte integral de processos normais e patológicos como desenvolvimento, remodelamento tecidual, crescimento e diferenciação celular, invasão e metástase. ${ }^{101}$

O remodelamento do tecido é um processo chave no desenvolvimento normal, na cura de doenças, no remodelamento ósseo e no desenvolvimento embrionário, bem como em condições patológicas como invasão celular, metástase e angiogênese tumoral. ${ }^{4,8,24,53,68,73,78}$

A degradação da MEC é mediada por algumas famílias de proteinases extracelulares. Tais famílias incluem as serinas-proteases, cisteína-proteases e metaloproteases da matriz (MMPs). ${ }^{8}$

\subsection{Metaloprotease da matriz}

Proteases extracelulares são necessárias em diversos processos relacionados com o desenvolvimento normal e com doenças. A habilidade de degradar proteínas extracelulares é essencial para células individuais interagirem com o ambiente ao redor e para organismos multicelulares se desenvolverem e funcionarem normalmente. ${ }^{86}$ Uma família de enzimas foi identificada em diferentes espécies, desde hidras até humanos, e chamadas, coletivamente, de metaloproteases de matriz (MMPs), dada sua dependência 
de íons metálicos para atividade catalítica e sua potente habilidade em degradar proteínas estruturais da MEC. ${ }^{87}$ Além dos substratos da MEC, as MMPs também são capazes de clivar moléculas de superfície celular de diversas maneiras. ${ }^{85}$ Dada a ampla variedade de proteínas que as MMPs são capazes de modificar, tais enzimas influenciam diversos processos fisiológicos e patológicos, incluindo aspectos do desenvolvimento embriogênico, morfogênese tecidual, processo de reparo e doenças inflamatórias. ${ }^{84}$

As MMPs são enzimas-chave responsáveis pela renovação da MEC e exercem um importante papel no desenvolvimento e na progressão de patologias humanas. ${ }^{3,8,33,53,78}$ MMPs compreendem um grupo de contínuo crescimento de enzimas proteolítica, dependentes de zinco que, de acordo com a especificidade do substrato e a homologia de seus domínios, são subdivididas em colagenases, gelatinases, estromelisinas (lisinas do estroma) e MMPs do tipo membrana. ${ }^{8}$ Juntas estas enzimas são capazes de degradar toda a estrutura protéica da MEC.

Devido à habilidade de alterar o destino celular e o desenvolvimento tecidual, as MMPs necessitam estar sob rígido controle. Primeiramente, foi demonstrado que as MMPs são sintetizadas como zimogênios inativos que requerem ativação ${ }^{31} \mathrm{e}$, posteriormente, mostrou-se a existência de inibidores endógenos de MMPs, chamados inibidores teciduais de metaloproteases (TIMPs). ${ }^{7}$ Depois disso, outros níveis de controle têm sido elucidados, no entanto, muitas etapas de complexidade ainda permanecem obscuras. Além disso, existem várias MMPs, cada uma com seu próprio perfil de expressão, localização na superfície celular, ativação, inibição e degradação, bem como 
seu próprio, às vezes amplo, espectro de substratos preferenciais. Desta maneira, múltiplas modificações, cada uma com seu próprio perfil regulatório, controlam as diferentes funções das MMPs in vivo. A multiplicidade das MMPs, com funções distintas e, às vezes, sobrepostas, provavelmente atua como uma proteção contra qualquer perda de controle regulatório. ${ }^{86}$

\subsubsection{Estrutura e função das MMPs}

A primeira publicação sobre metaloprotease da matriz foi em 1962 por Gross e Lapière. Eles observaram que durante o processo de metamorfose da rã, quando ocorre a reabsorção da sua cauda, havia a liberação de uma enzima que poderia atacar a tríplice hélice do colágeno. Desde então, várias MMPs têm sido estudadas e classificadas em 5 classes principais (colagenases, gelatinases, estromalisinas, tipo membrana e outras, incluindo matrilisinas), baseado na especificidade do substrato e na sua homologia interna. ${ }^{81}$

Metaloproteases da matriz são expressas por células estromais em respostas a estímulos, como também, pela maioria das células inflamatórias que invadem o tecido durante eventos de remodelamento in vivo. A presença do RNA mensageiro em células lesionadas e atividade de MMPs em lesões indicam o papel destas enzimas em processos patológicos. 
Enzimas proteolíticas são classificadas como exopeptidases e endopeptidases com base na ocorrência de clivagem de pontes peptídicas terminais ou internas, respectivamente. A maioria das endopeptidases é classificada como serina, cisteína, aspartato ou metaloprotease, baseado no seu mecanismo catalítico e sensibilidade a inibidores.

Um total de 25 MMPs de vertebrados e 22 MMPs homólogas de humanos foram identificadas. ${ }^{86}$ Cada uma das MMPs de vertebrados possui substratos distintos e, às vezes, comuns sendo que juntas elas são capazes de clivar numerosos substratos extracelulares, incluindo, virtualmente, todas as proteínas da MEC. ${ }^{84}$

As MMPs são referidas pelo seu nome ou de acordo com uma nomenclatura numérica seqüencial reservada para as MMPs de vertebrados. Além disso, elas são comumente agrupadas de acordo com suas unidades de domínio estrutural. Todas as MMPs possuem uma seqüência de sinalização Nterminal (ou pré-domínio), o qual é removido após direcionar a síntese da enzima para o retículo endoplasmático. Desta forma, a maioria das MMPs são secretadas; no entanto, seis destas apresentam domínio transmembrana e são expressas como enzimas de superfície celular. O pré-domínio é seguido por um pró-dominio, o qual mantem a latência da enzima até que este seja removido ou alterado. ${ }^{54}$

Gelatinase A e B (MMP-2 e MMP-9, respectivamente) são distinguidas pela inserção de três repetições cabeça-cauda ricas em cisteína, em seus domínios catalíticos. As MMPs do tipo membrana (MT-MMPs) possuem um domínio transmembrana de alça única e uma curta cauda C-terminal 
citoplasmática (MMPs 14, 15, 16 e 24) ou um domínio C-terminal hidrofóbico que atua como um sinal de ancoramento à membrana por glicosilfosfatidilinositol (GPI) (MMP-17 e MMP-25). Estes domínios exercem um papel essencial na localização de diversos eventos importantes de proteólise que ocorrem na superfície celular. ${ }^{86}$

A atividade da gelatinase $A$ foi observada no tecido sinovial reumatóide por Harris e Krane em 1972, que em retrospecto, era possivelmente a MMP-2. A atividade da gelatinase foi separada da colagenase-1 e da estromalisina-1 em meio de cultura de osso de coelho por Sellers et al, em 1978. No ano seguinte, Liotta achou uma enzima similar em tumor de rato que digeria a membrana basal do colágeno tipo IV. Isto permitiu uma denominação inicial de colagenase Tipo IV, contudo atualmente, uma denominação mais corriqueiramente encontrada é 72 kDa gelatinase. MMP-2 foi purificada de culturas de tumor de ratos, osso de coelhos, pele humana e tecido gengival. A seqüência da MMP-2 inclui um domínio com uma tripla repetição de fibronectina tipo II inserida no seu domínio catalítico, contribuindo para a ligação da enzima ao substrato da gelatina, isto faz da MMP-2, uma das metaloproteinases com estrutura mais longa. ${ }^{103}$

A gelatinase dos leucócitos polimorfonucleares foi descrita por Sopata et al em 1974, era uma forma latente ativada por mercúrio. Uma enzima similar encontrada em macrófagos de coelhos era capaz de digerir colágeno tipo $\mathrm{V}$, permitindo uma designação inicial de colagenase Tipo V. A atividade da colagenase e da gelatinase de neutrófilos foi separada, as enzimas purificadas e caracterizadas seguindo a seqüência de cDNA. Gelatinase B, 
estruturalmente, é a maior da gelatinases, incluindo três domínios de fibronectina e um domínio tipo colágeno tipo $\mathrm{V}$. O peso molecular de cerca de 92000 daltons permitiu uma outra designação; 92 kDa gelatinase. A TIMP-1 se liga a proMMP-9, produzindo um complexo que serve para regular a ativação e subseqüente atividade da enzima. ${ }^{103}$

A metaloprotease da matriz tipo-membrana-1 (MT1-MMP) ou metaloprotease da matriz 14 (MMP-14) apresenta um domínio transmembrana que pode ativar a ligação da pro-MMP-2 na superfície celular. Esta enzima é detectada em neoplasias malignas, no desenvolvimento embrionário, placenta e cartilagem. ${ }^{103}$

Devido ao fato das MMPs degradarem as proteínas da MEC, sua principal função tem sido referida como remodeladora dessa matriz. No entanto, as MMPs também atuam em substratos não pertencentes à matriz, incluindo reguladores de crescimento da superfície celular e ligados à matriz. Portanto, a regulação coordenada das MMPs e dos TIMPs governa a clivagem e a liberação de importantes fatores de crescimento e receptores da superfície celular. ${ }^{16}$ Estudos in vitro mostraram que a MMP-2 e MMP-9 são capazes de clivar proteoliticamente TGF- $\beta$. Além disso, análises fenotípicas de camundongos transgênicos indicam que ocorre interação genética entre MMPs e a cascata de sinalização de TGF- $\beta$. ${ }^{97,106}$ 


\subsubsection{Metaloprotease da matriz na Polpa e em Lesões Periapicais}

As MMPs são enzimas responsáveis pela degradação da matriz extracelular e estão presentes em condições inflamatórias como nas pulpites e periodontites. BIRKEDAL-HANSEN ${ }^{9}$ em 1995, relata que as MMPs são expressas em baixo nível nos tecidos normais, mas aumentadas durante a inflamação.

Em endodontia, as MMPs tem ganhado atenção em diversão estudos. O'BOSKEY; PANAGAKOS ${ }^{60}$ em 1998, propuseram que citocinas estimulam os níveis de produção de MMP-2 e MMP-9 em células do tecido conjuntivo pulpar humano em cultura de células e que estas MMPs podem desempenhar um papel importante na inflamação pulpar. No mesmo ano, TJADERHANE et al. ${ }^{96}$ sugerem que MMPs são ativadas por ácidos bacterianos e tem um papel crucial na destruição da dentina por cáries.

Utilizando de experimentos em cultura de células pulpares humanas, NAKATA et al. ${ }^{56}$, em 2000 , observaram a influência de extratos bacterianos anaeróbicos na produção de MMPs ( MMP-1 e -2) e de TIMPs (TIMP-1 e -2), por meio do teste ELISA. As bactérias gram negativas escolhidas foram: Prevotella intermédia, Fusobacterium nucleatum, Porphyromonas endodontalis e Porphyromonas gingivalis por estarem associadas à inflamação da polpa dentária. O estudo demonstrou que as células pulpares foram estimuladas a produzir MMP-1 e MMP-2 quando em contatos com o extrato bacteriano. Já a produção de TIMP-1 foi insignificantemente aumentada e os níveis de TIMP-2 
foram diminuídos quando em contato com o extrato, permitindo um aumento da produção de MMPs.

No ano seguinte, CHANG et al. ${ }^{18}$ procuraram verificar os efeitos de algumas citocinas: interleucina-1, fator de crescimento transformante- $\beta$, inibidores da síntese de proteína - cycloheximide (CD) e inibidores da proteína C quinase na produção e secreção de MMPs em cultura de células humanas, usando para isso o método da zimografia. A principal gelatinase secretada pela cultura de células pulpares foi a MMP-2, que migrou para a banda de $72 \mathrm{kDa}$; a menor banda observada foi de $92 \mathrm{kDa}$, correspondendo a MMP-9. Com este estudo, foi observado que citocinas inflamatórias e agentes farmacológicos estimulam os níveis de produção de MMP-2, e esta pode desempenhar um papel importante na inflamação.

As colagenases (MMP-1 e MMP-8) e as gelatinases (MMP-2 e MMP-9) estão presentes em fluidos de cistos radiculares. A expressão de MMP-8 aparece também em linhagem de células polimorfonucleadas, fibroblastos de polpas dentárias, odontoblastos, células epiteliais e células plasmáticas. Já os macrófagos expressam várias MMPs, incluindo colagenase 1 (MMP-1), gelatinase (MMP-2 e MMP-9), estromalisinas (MMP-3, MMP-7 e MMP-12). ${ }^{98}$

Durante o tratamento endodôntico, ocorre um decréscimo no exsudato proveniente dos canais radiculares e consequentemente nos níveis de MMP-8. Utilizando estudos com a MMP-8 e por meio de análises de Western Blotting e imuno-histoquímica, WAHLGREN et al. ${ }^{98}$, em 2002, coletaram exsudatos de canais radiculares durante cada uma das três sessões utilizadas na terapia endodôntica. A diminuição dos níveis de MMP-8 após a primeira sessão, se 
deu pela remoção do tecido pulpar e em casos de necropulpectomia pela instrumentação dos canais. A presença da degradação de proteínas da matriz extracelular indica a fase ativa no sítio inflamatório. Hipoteticamente, se numa terceira sessão houvesse ausência de MMP-8 no exsudato de canais radiculares, haveria reflexos de desaparecimento da inflamação e indícios de cura da peridontite apical. A presença dos níveis de MMP-8 no exsudato de canais radiculares serve de indicador bioquímico para a monitorização dos níveis de inflamação do tecido periapical.

Em 2002, SHIN et al. ${ }^{77}$ pesquisaram os níveis de MMP-1, -2 e -3 em polpa e lesões periapicais, por meio de estudos em imuno-histoquímica e teste ELISA. Neste estudo, os resultados da imunomarcação sugeriram que MMP-1 e MMP-3 são secretadas por leucócitos polimorfonucleares (PMNs), macrófagos, plasmócitos e linfócitos e apareceram localizadas na matriz extracelular ao redor destas. A MMP-2 foi mais observada em processos agudos, e imunomarcadas em células inflamatórias e fibroblastos. O teste ELISA inclui ambas as formas de MMP, ativa e latente, então a concentração elevada de MMPs nem sempre indica o estado de destruição tecidual. Contudo, as MMPs aparecem ser positivamente relacionadas com os sintomas dos pacientes, o qual se deve a elevação dos níveis de PGE2, induzindo a produção de colagenase em macrófagos.

GUSMAN; SANTANA; ZEHNDER ${ }^{30}$, em 2002, por meio de estudos de zimografia e testes ELISA, compararam os níveis de MMP-1, MMP-2, MMP-3 e MMP-9 em polpas sadias e inflamadas. Os autores observaram que os altos níveis de MMP-9 em polpas inflamadas e sua correlação com atividade 
gelatinolítica são sugestivas, apresentado papel chave como mediador do processo inflamatório pulpar humano. Na inflamação, a MMP-9 é abundante, sendo secretada, principalmente por leucócitos polimorfonucleares. Por isso, os neutrófilos e suas enzimas, podem ser a causas principais da caracterização da pulpite aguda. As demais MMPs estudadas não apresentaram aumento significativo entre as condições de normalidade para a patológica.

Após induzir lesões periapicais em ratos, LIN et al. ${ }^{42}$, em 2002, observaram a expressão de MMP-1, TIMP-1, IL-6 e COX-2. A imunohistoquímica e a hibridização in situ foram realizadas nos períodos experimentais $(5,10,15$ e 20 dias após a indução da lesão periapical). A proposta do estudo foi a administração de meloxican em um grupo de ratos e outros não receberam este tratamento. Os resultados demonstraram que uma redução de $43 \%$ da perda óssea (reabsorção óssea) e simultânea queda na percentagem da expressão de MMP-1 e IL-6 m-RNA. A COX-2 desempenha um importante papel na patogênese da lesão periapical por modular indiretamente a expressão de MMP-1 e IL-6.

Por meio de um estudo em culturas de células humanas, pulpares e do ligamento periodontal humanos, CHANG et al. ${ }^{17}$, em 2002, estimularam a secreção de metaloprotease da matriz, quando bacteróides produtores de pigmentos negros eram colocados em contato com o meio de cultura. As bactérias testadas, Porphyromonas endodontalis e Porphyromonas gengivalis, são especialmente associadas às infecções e abcessos de origem endodôntica. A zimografia demonstrou que a MMP que mais foi secretada migrou para 72 kDa, correspondendo a MMP-2, em menor número a MMP-9 
(92 kDa) apareceu em segundo lugar. Nos períodos avaliados de 1, 4 e 8 dias, a MMP-2 apareceu aumentar seu nível de expressão, enquanto que a MMP-9 não alterou seu padrão de expressão em relação ao tempo.

PALOSSAARI et al. $^{64}$, em 2003, estudaram o perfil da expressão de 19 matriz metaloproteinases (MMPs) e seus inibidores teciduais específicos (TIMP-1, -2 e -3) em cultura de odontoblastos humanos e em tecido pulpar. A metodologia foi composta por experimentos com RT-PCR (reverse transcriptase polymerase chain reaction), Western Blotting e zimografia. Outro objetivo deste estudo foi analisar a influência do fator de crescimento transformante- $\beta$ (TGF- $\beta$ ) e da proteína morfogenética óssea- 2 (BMP-2), nos níveis de expressão das MMPs. Os resultados demonstraram que odontoblastos e o tecido pulpar expressam MMP-1, -2, -9, -10, -11, - 13, -14, $15,-16,-17,-19,-20$ e -23 , como também as TIMP-1, -2 e -3. A MMP-3 e a MMP-12 não foram expressas na polpa e nos odontoblastos. As MMP-7, --8, 24 e -25 foram expressas somente nos odontoblastos. O TGF- $\beta$ sozinho e junto com a BMP-2 significantemente regularam positivamente a atividade de MMP-9 em odontoblastos, com resposta negativa ao tecido pulpar. Os autores concluíram que as MMPs desempenham um importante papel no processo fisiológico e patológico do complexo dentina-polpa, uma vez que participam na mineralização e nos processos de reparação tecidual, onde ocorrem mudanças na organização da matriz do tecido pulpar.

Em 2004, HUANG et al. ${ }^{32}$, também em cultura de células pulpares humanas, procuraram estudar os efeitos de vários agentes farmacológicos: Herbamicin A (inibidor da tirosina quinase), dexametazona (NF-kB) , NS-398 
(inibidor seletivo da COX-2), SB203580 (inibidor p38), PD098059 (inibidor ERK) e LY294002 (inibidor PI3K) na produção e secreção de MMPs. Por meio da zimografia, nos períodos de 1, 2 e 4 dias, a principal MMP secretada foi a MMP-2, uma banda menor de MMP-9 foi observada. O estudo demonstrou que dentre os fármacos estudados, o NS-398, a dexamethazona e herbamicin A podem regular a produção de MMP-2.

Em 2005, LEONARDI; CALTABIANO; LORETO ${ }^{40}$ estudaram por meio de estudo de imunohistoquímica a expressão de MMP-13 (colagenase-3) em lesões periapicais. Foram selecionados para o estudo 17 granulomas periapicais, sendo destes 10 epiteliados. A proposta do trabalho foi verificar, por meio de avaliação qualitativa da imunomarcações, se a presença de MMP13 é verificada em maior grau nos granulomas com epitélio. Os resultados demonstraram que a MMP-13 estão em maior número nestes casos, influenciando não somente a migração epitelial, mas também a invasão deste no tecido de granulação.

\subsection{Inibidores Teciduais de Metaloproteases (TIMPs)}

Inibidores teciduais de metaloproteases são os maiores inibidores celulares de MMPs. Quatro TIMPs $(-1,-2,-3$ e -4$)$ tem sido clonadas, purificadas e caracterizadas, apresentando muitas similaridades básicas, todavia exibem distintas características estruturais, propriedades bioquímicas e 
padrões de expressão. Isto sugere que cada TIMP possui um específico papel in vivo. ${ }^{4}$

As TIMPs são proteínas multifuncionais, possuem peso molecular em torno de $21 \mathrm{KDa}$ e são secretadas na MEC, contudo podem ser encontradas próximas à superfície celular quando associadas com alguma outra proteína ligada à membrana, por exemplo a TIMP-2. ${ }^{4}$ São expressas por muitos tipos celulares incluindo fibroblastos, queratinócitos, macrófagos e células endoteliais. $^{9}$

As TIMPs interferem no crescimento e sobrevivência celular. Distúrbios entre MMPs e TIMPS estão envolvidas na etiologia de algumas doenças como a artrite, enfisema pulmonar, arteriosclerose e periodontites, na qual a perda da MEC é a maior característica. Por esta razão existe um grande interesse no desenvolvimento de inibidores sintéticos de MMPs, o qual poderiam ser usados na terapia médica e odontológica. ${ }^{81}$

\subsection{Gene Supressor RECK}

O fenômeno da reversão de células transformadas e tumorais para um fenótipo normal, têm permitido abordar o papel de oncogenes e de genes supressores de tumor não só no controle da proliferação celular normal como, também, na transformação celular, e nos mecanismos de transdução de sinais. 
Com o objetivo de estudar os mecanismos moleculares envolvidos na transformação maligna têm-se isolado e caracterizado cDNAs, os quais, quando super-expressos, induzem a reversão fenotípica da linhagem DT, uma sublinhagem de células $\mathrm{NIH}-3 \mathrm{~T} 3$ transformadas com v-Ki-ras. ${ }^{36,57,58,91,92}$ Utilizando esta abordagem, foi isolado um cDNA que codifica uma nova glicoproteína de membrana denominada RECK (reversion-inducing cysteinerich protein with Kazal motifs). ${ }^{92}$

Tanto o cDNA humano quanto o de camundongo codificam para uma proteína composta por 971 resíduos de aminoácidos, demonstrando uma identidade de $93 \%$ entre ambos. A proteína RECK é rica em cisteína e contém regiões hidrofóbicas tanto na região $\mathrm{NH} 2$ - terminal quanto na porção $\mathrm{COOH}$ terminal. A seqüência peptídica da proteína humana madura expressa em células de mamíferos, indica que a porção NH2- hidrofóbica terminal (26 resíduos) funciona como um sinal peptídico, enquanto que a porção $\mathrm{COOH}$ terminal parece funcionar como um sinal para a âncora de glicosilfosfatidilinusitol pela qual RECK é ancorada a membrana plasmática. A porção mediana da proteína contém três domínios semelhantes aos inibidores de serina-proteases: domínios condizentes com "motifs" de Kazal. Além disso, foram detectadas duas regiões de repetição de fraca homologia com o fator de crescimento epidermal, "motif" de cisteína e cinco sítios com potencial de glicosilação. ${ }^{92}$

O gene RECK é expresso em diversos tecidos humanos normais, porém, sua expressão é reprimida durante a transformação celular, uma vez que a expressão deste gene não foi detectada nas inúmeras linhagens 
tumorais analisadas. A expressão constitutiva do gene RECK em linhagens celulares malignas, incluindo HT1080, B16, SW48, A549, HeLa e A673, resulta em supressão da atividade invasiva e metastática destas células. Além disso, estudos demonstram que a forma solúvel da proteína RECK retém a habilidade de supressão da invasão tumoral. Análise de meio condicionado de culturas celulares em ensaios de zimografia, mostraram que a atividade de uma metaloproteinase de matriz (MMP-9), enzima envolvida em processos de invasão tumoral e metástase por meio da degradação do colágeno da matriz extracelular, estava drasticamente reduzida nos transfectantes de RECK. Ensaios de Northern Blot sugeriram que tal regulação era um evento póstranscricional, já que não foram observados diferenças nos níveis de mRNA. Além disso, demonstrou-se que a associação de RECK com a membrana plasmáica era necessária para a supressão da atividade de MMP-9 já que a forma solúvel de RECK não apresentou tal resultado. ${ }^{92}$

Por meio de ensaios bioquímicos, foi mostrado que a proteína RECK purificada se liga a MMP-9 e inibe a sua atividade proteolítica, sendo este mecanismo ainda não explorado. ${ }^{92}$

A proteína RECK solúvel purificada parece ser capaz de se ligar a proMMP-9 purificada e inibir a atividade proteolítica desta enzima in vitro. No entanto, o potencial de inibição parece ser menor que o observado para inibir TIMP-1. O truncamento artificial da porção $\mathrm{COOH}$ terminal e/ou a possibilidade de inativação durante a purificação podem refletir o potencial relativamente baixo de inibição da atividade de MMP-9 mediada por RECK na membrana da célula. É interessante notar que uma proteína relatada como sendo relacionada 
com inibidores de uma classe de proteases (serina-proteases) mostra-se capaz de regular um membro de outra classe de protases (MMPs). ${ }^{92}$

Relatos recentes mostram que RECK regula negativamente, além da MMP-9, duas outras MMPs: MMP-2 e MT1-MMP 61 ; revisto por RHEE; COUSSENS $^{70}$ em 2002. O processamento da pro-MMP-2 ocorre por meio de duas clivagens proteolíticas consecutivas, as quais ocorrem, preferencialmente, na membrana plasmática. ${ }^{25}$ Têm sido descrito que o restabelecimento da expressão de RECK em linhagem de fibrossarcoma resulta em uma diminuição tanto da forma intermediária quanto da forma ativa de MMP-2, sugerindo que RECK regula a ativação da pro-MMP-2 por inibir duas enzimas proteolíticas necessárias para o seu processamento, especificamente as enzimas MT1MMP e a própria MMP-2 ativa. ${ }^{61}$

As funções biológicas de RECK in vivo foram exploradas, recentemente, por meio de experimentos com camundongos "Knock-out" e de ensaios de tumorigenicidade em camundongos "nude". ${ }^{61}$ Camundongos no qual a proteína RECK funcional está ausente morrem em torno do décimo dia da fase embrionária com deficiências de fibras de colágeno, desorganização da lâmina basal e comprometimento do desenvolvimento vascular. Este fenótipo foi parcialmente suprimido pelo "knock-out" do gene correspondente à MMP-2, indicando que a regulação da atividade de MMP-2 mediada por RECK tem um papel fisiológico. 
MATERIAL E MÉTODOS 


\section{4- MATERIAL E MÉTODOS}

\subsection{Amostras teciduais de lesões periapicais para RT-PCR}

Os tecidos provenientes de 15 cirurgias paraendodônticas, foram coletados, lavados em solução salina para remoção do excesso de sangue e divididos em 2 partes relativamente iguais. Esses tecidos periapicais coletados foram procedentes de casos clínicos onde foi constatado insucesso após retratamento endodôntico da clínica de Endodontia da Faculdade de Odontologia de Bauru. Uma parte da amostra foi acondicionada em solução de formol tamponado à 10\% (Merck, Darmstedt, Germany) e encaminhada para o Serviço de Patologia da Faculdade de Odontologia de Bauru para laudo anatomopatológico; a outra parte foi colocada em contato com RNAlater ${ }^{\circledR}$ (Ambion, Texas, USA) e mantida em $-70^{\circ} \mathrm{C}$, para posterior obtenção do RNA total. Após análise microscópica dos tecidos coletados, 8 eram granulomas periapicais, 6 cistos periapicais e 1 cicatriz apical. Os tecidos em RNAlater ${ }^{\circledR}$ foram encaminhados para o IQ (Instituto de Química da Universidade de São Paulo), para realização dos ensaios em RT-PCR.

\subsection{Preparação de RNA total}

Os tecidos foram macerados manualmente em cadinho de porcelana na presença de nitrôgenio líquido e, posteriormente, lisados em solução de isotiocianato de guanidina $4 \mathrm{M}$, citrato de sódio $25 \mathrm{mM} \mathrm{pH} 7$, e 
betamercaptoetanol $0,1 \mathrm{M}$. Os tecidos lisados foram transferidos para tubos de polialômero contendo solução de cloreto de césio $5,7 \mathrm{M}$, acetato de sódio $25 \mathrm{mM}$ pH5,0 e centrifugados a 37000rpm por, aproximadamente, 18 horas a $20^{\circ} \mathrm{C} .{ }^{20}$ O precipitado de RNA foi redissolvido em volume adequado de água estéril. Após a quantificação espectrofotométrica, a qualidade do RNA é visualizada em gel de agarose contendo tiocianato de guanidina 20mM.

\subsection{Ensaios de Real Time PCR}

\subsubsection{Síntese da primeira fita do cDNA}

O RNA total resultante do item 4.2 foi utilizado como molde (template) para a síntese de cDNA em uma reação de transcrição reversa. Desta forma, foram preparadas as reações contendo $1 \mu \mathrm{g}$ de RNA total, proveniente de cada uma das amostras utilizadas separadamente, adicionando para cada reação: $1 \mu \mathrm{L}$ de Oligo dT 500 $\mathrm{g} / \mathrm{ml}$ (Amersham Biosciences, Inglaterra), 0,5 $\mu \mathrm{L}$ de "Random Primer" $100 \eta \mathrm{g} / \mu \mathrm{L}$ e $\mathrm{H}_{2} \mathrm{O}$ para um volume final de $12 \mu \mathrm{L}$. As amostras foram incubadas a $75^{\circ} \mathrm{C}$ por 10 minutos e, em seguida, adicionou-se $7 \mu l$ de uma solução contendo $2 \mu \mathrm{l}$ de Buffer $5 x$ para a enzima Super Script (Invitrogen, Califórnia, USA), $2 \mu \mathrm{L}$ de DTT (Ditiotrietol) e $0,5 \mu \mathrm{L}$ de RNase OUT $40 \mathrm{U} / \mu \mathrm{L}$ e $2,5 \mu \mathrm{L}$ de $\mathrm{H}_{2} \mathrm{O}$ foram adicionados para cada amostra de RNA. Houve uma nova incubação de $25^{\circ} \mathrm{C}$ por 10 minutos, $42^{\circ} \mathrm{C}$ por 2 minutos, sendo então adicionado $1 \mu \mathrm{L}$ da enzima SuperScript 200U/ $\mu$ l (Invitrogen Carlsbad, Califórnia, USA). 
A reação enzimática ocorreu num período de incubação de 2 horas a $42^{\circ} \mathrm{C}$. Em seguida, para inativação da enzima, a amostra foi incubada a $72^{\circ} \mathrm{C}$ por 10 minutos. Visando degradar o RNA, foi adicionado $1 \mu \mathrm{L}$ de RNase $\mathrm{H}$ $5 \mathrm{U} / \mu \mathrm{L}$ em cada tubo e estes novamente foram incubados a $37^{\circ} \mathrm{C}$ por 30 minutos seguidos por mais 10 minutos à $72{ }^{\circ} \mathrm{C}$, para inativação da RNase $\mathrm{H}$. Posteriormente, as amostras foram diluídas em $60 \mu \mathrm{L}$ de TE.

\subsubsection{Controle da qualidade do cDNA}

Para confirmar a qualidade do cDNA sintetizado, foram realizadas, como controle, reações de PCR utilizando um diferente conjunto de "primer" (para o gene GAPDH) e, como molde, o cDNA sintetizado em 4.3.1. Cada reação foi montada de forma que apresentasse uma concentração final de $1 x$ para 0 Tampão de Reação (Biolase), 1,5mM de $\mathrm{MgCl} 2,0,2 \mathrm{mM}$ de dNTP, 0,2 $\mu \mathrm{M}$ do "primer" (Forward e Reverse), enzima Taq (Biolase) e a fita molde (template).

Nas reações onde foi utilizado o "primer" GAPDH foi utilizado um programa de $94^{\circ} \mathrm{C}$ por 2 minutos, 35 ciclos de $94^{\circ} \mathrm{C}$ por 30 segundos, $56^{\circ} \mathrm{C}$ por 30 segundos e $72^{\circ} \mathrm{C}$ por 45 segundos e, após os ciclos, $72^{\circ} \mathrm{C}$ por 6 minutos. As reações foram posteriormente analisadas em um gel de agarose 1\% contendo Brometo de Etídeo.

\subsection{Confirmação dos genes por Real-Time PCR}

\subsubsection{Desenho dos "primers"}


Os "primers" que foram utilizados para a amplificação dos genes nos experimentos de Real-Time PCR foram desenhados com o auxílio do programa PrimerExpress (Applied Biosystems, Califórnia, USA), o qual desenha "primers" com as características necessárias para os experimentos de Real-Time PCR no termociclador $\mathrm{ABI}$ 5700. As principais características destes oligos são: amplificar fragmentos cujo tamanho máximo não exceda 20bp, quantidade moderada de CG (40-60\%), não possuir a capacidade de anelar entre si ou formarem estrutura secundária, temperatura de anelemamento entre $58^{\circ} \mathrm{C}$ e $60^{\circ} \mathrm{C} .^{11}$

Levando-se em consideração os parâmetros acima enumerados, os "primers" foram desenhados para cada um dos genes estudados:

hRECK

F: 5' TGCAAGCAGGCATCTTCAAA 3'

R: 5' ACCGAGCCCATTTCATTTCTG 3'

hGAPDH

F: 5' ACCCACTCCTCCACCTTTGA 3'

R: 5' CTGTTGCTGTAGCCAAATTCGT 3'

\section{hMMP-2}

F: 5' AGCTCCCGGAAAAGATTGATG3'

R: 5' CAGGGTGCTGGCTGAGTAGAT3' 


\section{hMMP-9}

F: 5' CCTGGAGACCTGAGAACCAATC3'

R: 5' GATTTCGACTCTCCACGCATCT3'

hMMP-14

F: 5'GCAGAAGTTTTACGGCTTGCA3'

R: 5'TCGAACATTGGCCTTGATCTC3'

hTIMP-1

F: 5' CCGCAGCGAGGAGTTTCTC3'

R: 5' GAGCTAAGCTCAGGCTGTTCCA3'

hTIMP-2

F: 5' TGAGCACCACCCAGAAGAAGA3'

R: 5' AGGAGATGTAGCACGGGATCA3'

\subsubsection{Confirmação da expressão diferencial}

Para a quantificação do produto formado durante a reação de Real-Time PCR foi utilizado o reagente SYBR ${ }^{\circledR}$ Green Dye (Applied Biosystems, Califórnia, USA). O SYBER Green Dye possui afinidade pela menor curva da dupla fita de DNA. Quando não está ligado ao DNA, emite uma pequena fluorescência no comprimento de onda de $520 \eta \mathrm{m}$, entretanto, quando se liga a dupla fita de DNA, a fluorescência é aumenta cerca de 100 vezes, permitindo então a detecção do produto do PCR em tempo real. ${ }^{39}$ 
O gerenciamento do termociclador e a coleta dos dados gerados durante a amplificação são realizados pelo programa ABI-Manager SDS (Roche). Utilizando o mesmo programa, foi escolhida a concentração de "primers" que resultaram em uma formação de "primer-dimer" mínima, ou inexistente, e a menor variação entre as duplicatas.

Todas as reações de Real-Time PCR foram realizadas em duplicata. Como fita molde, foi utilizado $3 \mu \mathrm{L}$ de cDNA sintetizado anteriormente, $3 \mu \mathrm{L}$ de "primer" na concentração final de 600ๆM e $6 \mu \mathrm{L}$ do SYBER Green Dye. O aparelho $\mathrm{ABI} 5700$ trabalha com placas de 96 poços, e todas as reações foram montadas tomando-se precauções para que na placa não se depositasse pó, talco ou outras partículas que pudessem interferir na leitura da fluorescência.

$\mathrm{Na}$ análise inicial dos dados, realizada por meio do programa $\mathrm{ABI}-$ Manager SDS, foi definido, manualmente, um limiar que estivesse na fase exponencial de amplificação do gene. Assim que é selecionado o limiar, da intersecção deste com a curva de amplificação, é obtido o Ct daquela amostra "Threshold Cycle" (Limiar do Ciclo), que é definido como o ciclo onde a fluorescência se encontra estatisticamente acima do background. Assim, temos que, quanto maior a concentração de um gene, mais rapidamente a sua curva de amplificação irá atingir o limiar e menor será o seu Ct. Conseqüentemente, quanto menor a sua concentração, maior o seu Ct. Portanto, podemos dizer que a diferença de expressão de um gene, que está sendo analisado em diferentes amostras, pode ser dada pela diferença dos seus Cts frente a um determinado limiar. 
Quando se analisam duas ou mais amostras em um experimento de Real-Time PCR, tem-se freqüentemente uma variação da concentração de cDNA entre elas, então, para que os dados possam ser comparados, é necessário que estes sejam previamente normalizados. Para análise dos dados provenientes de experimentos de Real-Time PCR foi realizada uma quantificação relativa por meio da obtenção de uma curva de um gene que não possui alteração de expressão nas amostras analisadas, e então, para cada amostra, a expressão do gene que está sendo estudada foi determinada em função da expressão do gene controle. Assim, para cada cDNA analisado eram feitas duas reações, uma utilizando "primers" para o gene analisado e a outra utilizando "primers" para um controle interno. Terminada a reação, era fornecido ao ABI-Manager SDS um limiar e então o programa retornava o Ct de cada reação.

A partir desses cálculos, foi possível analisar a diferença de formação do produto do PCR, que está diretamente ligado à expressão do gene entre as amostras analisadas.

\subsubsection{Análise estatística}

Análise entre granulomas e cistos periapicais foram realizados por meio do teste " $\mathrm{t}$ ". Para todas as análises, valores de $\mathrm{p}<0,05$ foram considerados estatisticamente significantes. Todos os testes estatísticos foram realizados por meio do programa GraphPad Prism 3.0 (GraphPad Software Inc, EUA). 
A correlação de transcritos para MMP-2, -9 e -14, TIMP-1, -2 e RECK foi realizado pelo teste de Pearson, com o auxílio do GraphPad Prism 3.0 software (GraphPad Software Inc, EUA)

\subsection{Amostras teciduais de lesões periapicais para Imuno-histoquímica}

Os tecidos provenientes de 30 cirurgias paraendodônticas foram coletados, lavados em soro fisiológico, acondicionados em solução de formol à 10\% e encaminhada para o Serviço de Patologia da Faculdade de Odontologia de Bauru para laudo anatomopatológico. Esses tecidos periapicais coletados foram procedentes de casos clínicos onde foi constatado insucesso após retratamento endodôntico da clínica de Endodontia da Faculdade de Odontologia de Bauru. As lâminas dos tecidos biopsiados foram analisadas, selecionando uma amostra somente constituída de 10 granulomas periapicais. Os critérios de inclusão e exclusão da amostra destinada à imuno-histoquímica foram:

- Tamanho do tecido coletado: Amostras de granulomas que tiverem um fragmento mínimo de 0,8 x 0,8.

- Amostras de tecido mais representativas, com história clínica e evolução do caso clínico foram incluídas.

- Pacientes com histórico de medicação antiinflamatória e antibiótica prévia a cirurgia foram excluídos. Diversos estudos demonstram a interferência na produção de MMP na presença de fármacos. ${ }^{32,64}$ 
O exame microscópico da lâmina coradas em hematoxilina e eosina foi realizado. Uma vez a amostra selecionada, os blocos de parafina contendo as lesões foram cortados em $3 \mu \mathrm{m}$ e depositados em lâminas silanizadas (Super Frost Plus, Erviegas Instrumental Cirúrgico Ltda, São Paulo, Brasil).

A caracterização imuno-histoquímica das células foi realizada usandose o método da imunoperoxidase (Streptoavidina-Biotina) e seguiu o seguinte protocolo para sua execução:

As amostras selecionadas foram desparafinizadas e hidratadas por meio de imersão em xilol (3 banhos de 5 minutos cada), álcool absoluto (1 vez por 3 minutos cada), álcool etílico 95\% (1 vez por 3 minutos), álcool 70\% (1 vez por 3 minutos), solução fosfato salina tamponada (PBS), por 5 minutos. Seguidos de incubação em peróxido de hidrogênio a 3\%, diluído em PBS, pH 7.2 por 40 minutos, para bloqueio da peroxidase endógena. Após esta etapa, as lâminas foram novamente lavadas em PBS por 5 minutos e imersas em tampão citrato (DAKO-P4809), $\mathrm{pH}=6.0$, aquecido a $95^{\circ} \mathrm{C}$, para exposição antigênica, por 20 minutos. Após serem lavadas em PBS por 5 minutos, todas as lâminas foram incubadas com soro de leite a 3\% em água destilada por 20 minutos, a fim de se obter o bloqueio das ligações protéicas inespecíficas. Em seguida as lâminas foram secas com papel absorvente e incubadas com os anticorpos primários, por 18 horas. Foram utilizados anticorpos policlonais anti-MMP-2 (8B4 sc - mouse 13595, Santa Cruz Biotechnology INC, Santa Cruz, CA, USA), anti-MMP-9 (C20 sc- goat 6840, Santa Cruz Biotechnology) e anticorpos policlonais anti-CD68 (C18 sc- goat 7082, Santa Cruz Biotechnology) diluídos 
em PBS associado a $1 \%$ de soro albumina bovina (PBS-BSA 1\%). Para a MMP-2, -9 e CD68+ a diluição foi de 1:100.

Após o período de incubação com o anticorpo primário, as amostras foram lavadas em PBS e incubadas com anticorpo secundário universal (Kit DAKO, LSAB + systems-HRP - KO690), utilizado conforme fabricação do fabricante. Esse anticorpo secundário é biotinilado, associado à biotina e moléculas de streptoavidina conjugada com a peroxidase. Após esta etapa, as lâminas são novamente lavadas por 5 minutos em PBS e posteriormente incubadas em uma solução de 3,3'-Diaminobenzidina (DAB) diluída em temperatura ambiente (KitDako - líquido DAB substrate -chromogen system). Após este tempo, as lâminas foram lavadas em água destilada, desidratadas com alccóis, pasadas em xilol (3 vezes) e coradas com hematoxilina de Harrys por 5 minutos. Após este processo as lâminas foram montadas com Entellan.

\subsubsection{Controle positivo e negativo}

O controle positivo para as reações envolvendo Metaloproteases foi o câncer de mama humano ${ }^{40}$ que foi processado da mesma maneira que as amostras testes. O controle positivo é indicativo da correta preparação da amostra e realização adequada de todas as etapas da coloração. Para o controle negativo foi utilizado o tecido deste estudo (granuloma periapical), não contendo o antígeno alvo, ou seja, não aplicando o anticorpo primário, substituíndo por PBS-BSA a 1\%. 
RESULTADOS 


\section{RESULTADOS}

As 15 amostras coletadas (14 lesões periapicais entre granulomas e cistos e 01 cicatriz periapical) foram submetidas ao Real time RT-PCR.

\subsection{Expressão das MMP-2 em granulomas, cistos e cicatriz periapicais.}

Os níveis médios da expressão relativa das MMP-2 apareceram nas amostras pesquisadas (Figuras 1 e 2), alternado seus níveis entre granulomas, cistos e cicatriz periapicais. Entre os granulomas e cistos periapicais, os níveis de expressão desta metaloprotease da matriz não apresentaram diferença estatisticamente significante, quando comparadas entre si. A amostra $C 3$, na figura 1, um cisto periapical, apresentou o maior pico de expressão de MMP-2. Os menores índices (abaixo de 0,2) de granulomas e cistos periapicais (amostras G1, C4, G7 e G8) se equipararam à cicatriz periapical (Figura 1). 

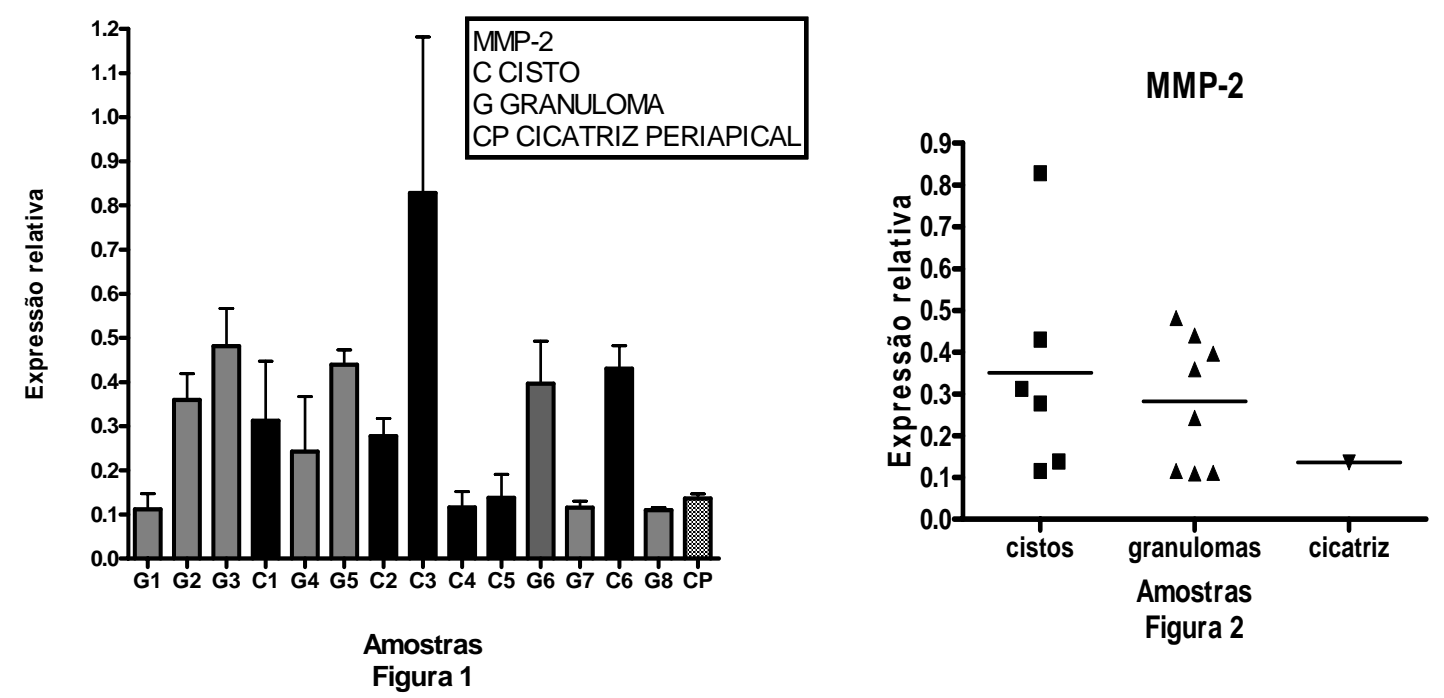

Figura 1: Níveis médios de expressão das MMP-2 entre granulomas, cistos e cicatriz periapicais. Figura 2: Níveis médios de expressão das MMP-2 nos grupos das amostras (gráfico de dispersão).

\subsection{Expressão das MMP-9 em granulomas, cistos e cicatriz periapicais}

Os níveis médios da expressão relativa das MMP-9 apareceram nas amostras pesquisadas comportando-se de forma diferente quando comparadas à MMP-2 (Figura 3 e 4). Entre os granulomas e cistos periapicais, os níveis de expressão de MMP-9 não apresentaram diferença estatisticamente significante, quando comparadas entre si. A amostra C6, um cisto periapical, apresentou o maior pico de expressão de MMP-9. Os menores índices foram das amostras de granulomas G1, G7 e G8 e de cistos C4 e C5, se equiparando à cicatriz periapical. 

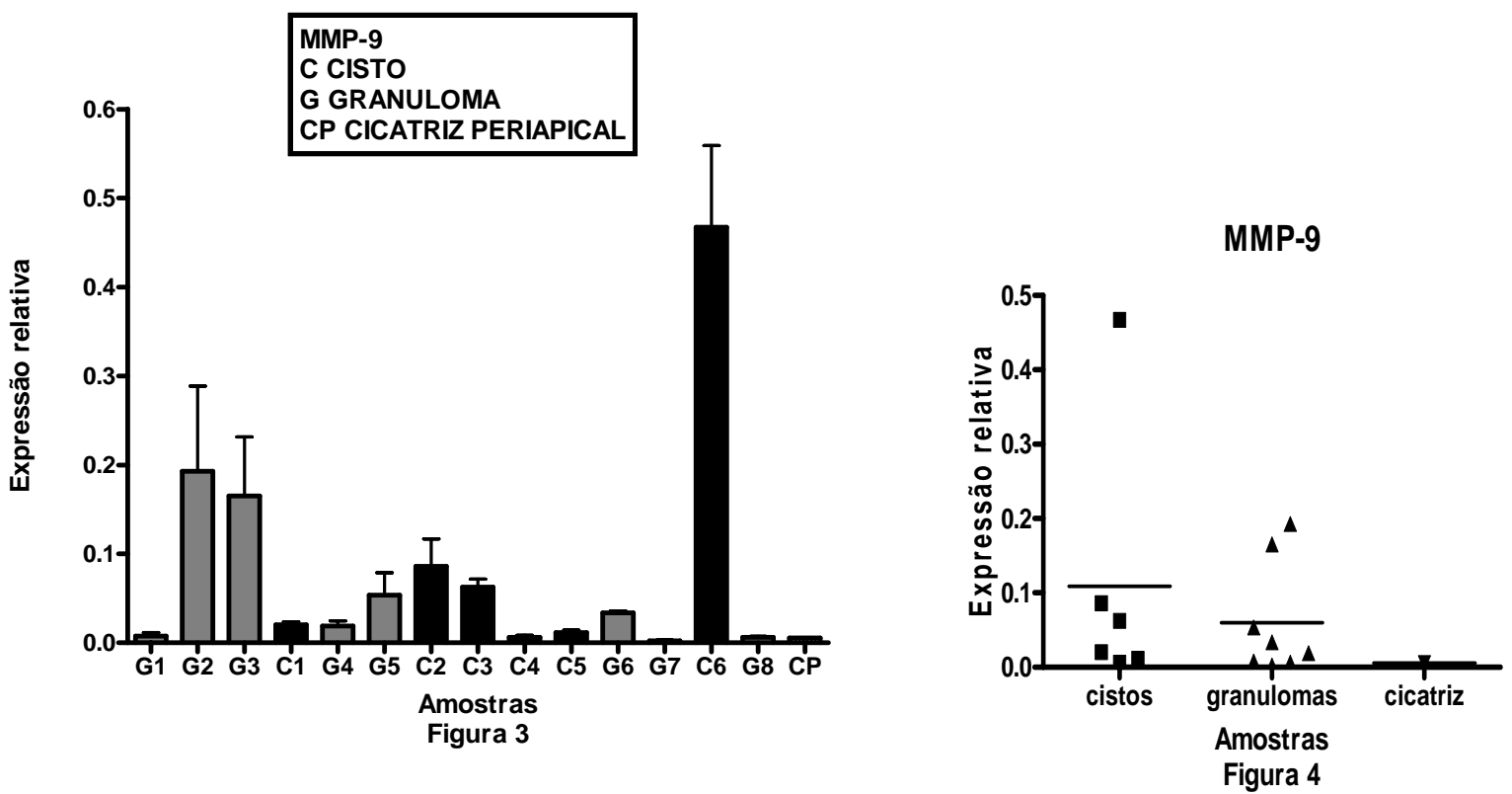

Figura 3: Níveis médios de expressão das MMP-9 entre granulomas, cistos e cicatriz periapicais. Figura 4: Níveis médios de expressão das MMP-9 nos grupos das amostras (gráfico de dispersão).

\subsection{Expressão de RECK em granulomas, cistos e cicatriz periapicais}

Os níveis médios da expressão relativa de RECK apresentaram-se, razoavelmente, bem uniformes entre as amostras pesquisadas, independente do diagnóstico anatomopatológico, não havendo diferença estatística significante entre as patologias estudadas.

Os valores médios da expressão relativa de RECK de granulomas, cistos e cicatriz periapicais são demonstrados na figura 5 e 6 . A amostra C3, um cisto periapical, revela um alto índice de expressão relativa de RECK em relação às demais amostras, que mantiveram um padrão de expressão bem menor (Figura 5). 

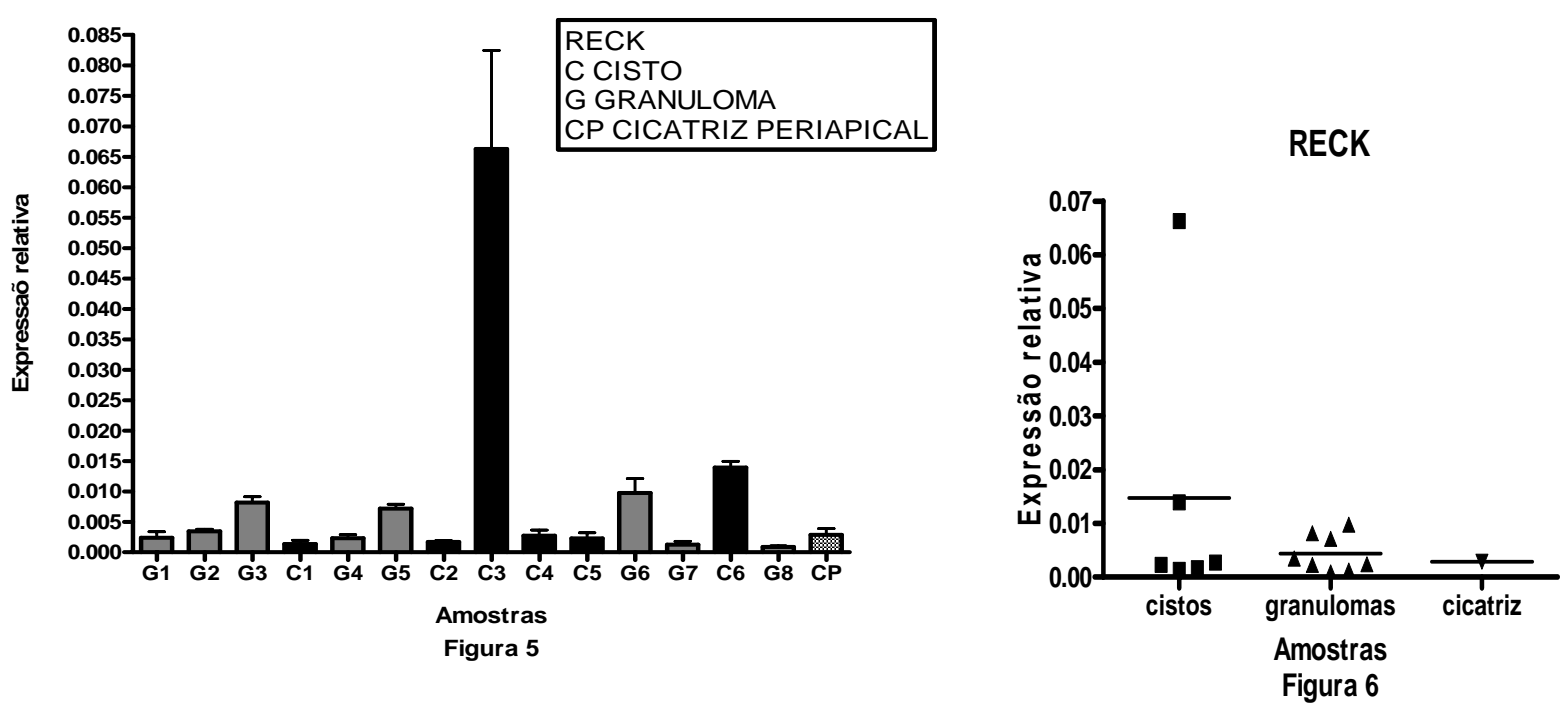

Figura 5: Níveis médios de expressão de RECK entre granulomas, cistos e cicatriz periapicais. Figura 6: Níveis médios de expressão de RECK nos grupos das amostras (gráfico de dispersão).

\subsection{Expressão de TIMP-1 em granulomas, cistos e cicatriz periapicais}

Os níveis médios da expressão relativa de TIMP-1 se apresentaram bem uniformes entre as amostras pesquisadas, independente do diagnóstico anatomopatológico, não havendo diferença estatística significante entre as patologias estudadas.

Os valores médios da expressão relativa de TIMP-1 de granulomas, cistos e cicatriz periapicais são demonstrados na figura 7 e 8. A exceção ocorreu na amostra $\mathrm{C} 2$, um cisto periapical, que revelou um alto índice de expressão relativa de TIMP-1 em relação às demais, que mantiveram um padrão de expressão menor e mais uniforme(Figura 7). 


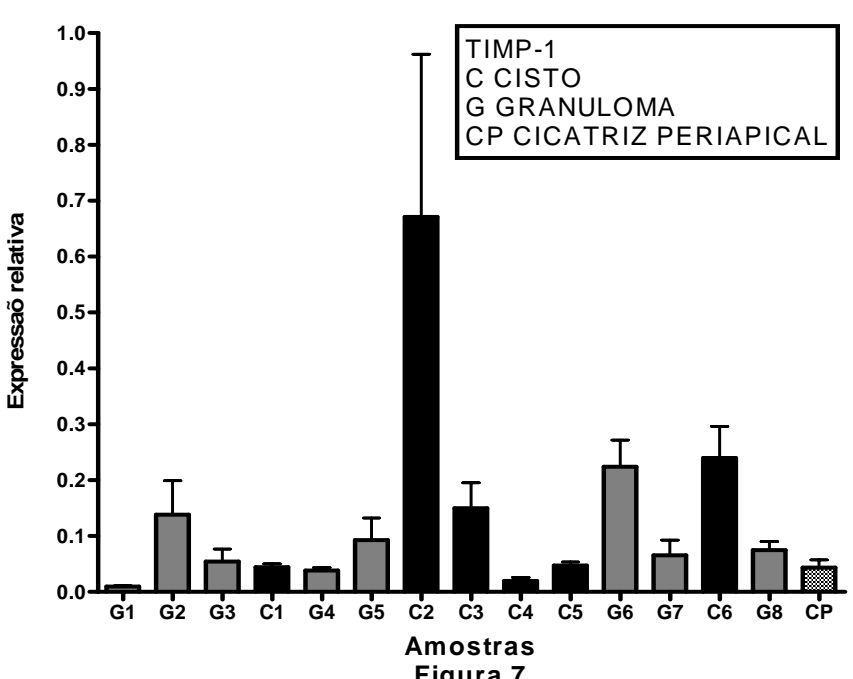

Figura 7
TIMP-1

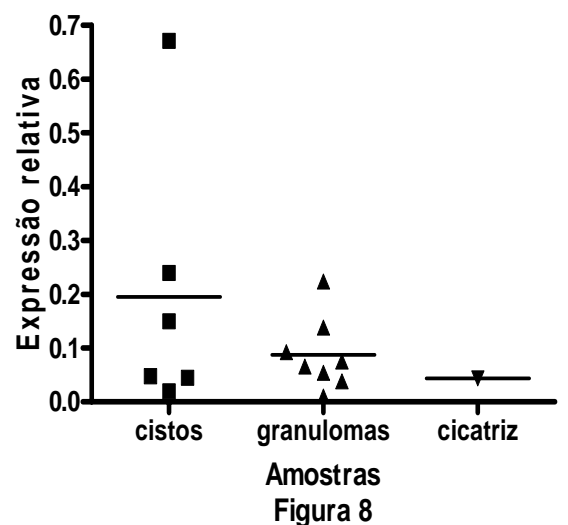

Figura 7: Níveis médios de expressão de TIMP-1 entre granulomas, cistos e cicatriz periapicais. Figura 8: Níveis médios de expressão de TIMP-1 nos grupos das amostras (gráfico de dispersão).

\subsection{Expressão de TIMP-2 em granulomas, cistos periapicais e cicatriz periapicais}

Os níveis médios da expressão relativa de TIMP-2 aparecem nas amostras pesquisadas, comportando-se de forma diferente quando comparadas à TIMP-1 (Figura 9). Entre os granulomas e cistos periapicais, os níveis médios de expressão deste inibidor de metaloprotease da matriz não apresentaram diferença estatisticamente significante, quando comparadas entre si. A amostra C3 e C6, cistos periapicais, que revelaram um alto índice de expressão relativa de TIMP-2 em relação às demais, que mantiveram um padrão de expressão menor e mais uniforme (Figura 7). 


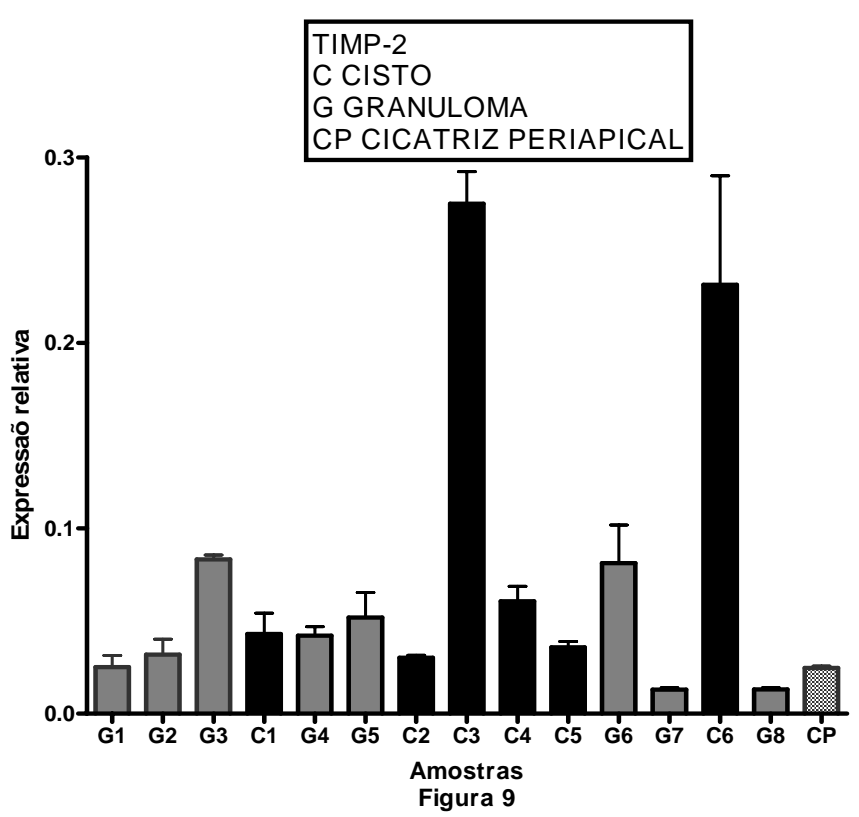

TIMP-2

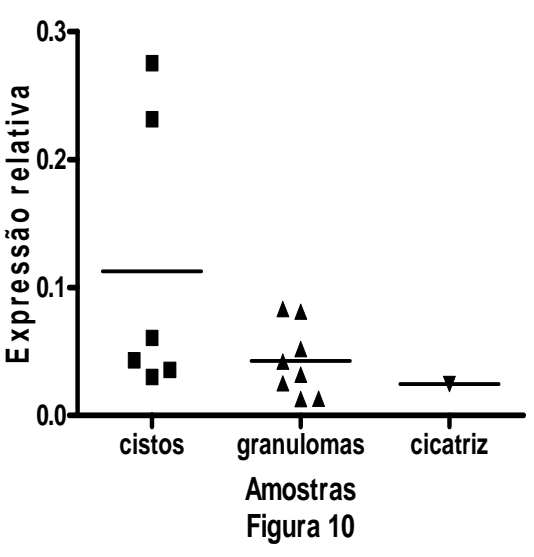

Figura 9: Níveis médios de expressão de TIMP-2 entre granulomas, cistos e cicatriz periapicais. Figura 10: Níveis médios de expressão de TIMP-2 nos grupos das amostras (gráfico de dispersão).

\subsection{Expressão de MMP-14 em granulomas, cistos e cicatriz periapicais}

Os níveis médios da expressão relativa de MMP-14 aparecem nas amostras pesquisadas (Figura 11 e 12), alternando seus níveis entre granulomas, cistos e cicatriz periapical. Entre os granulomas e cistos periapicais os níveis de expressão desta metaloprotease da matriz não apresentaram diferença estatisticamente significante, quando comparadas entre si. 

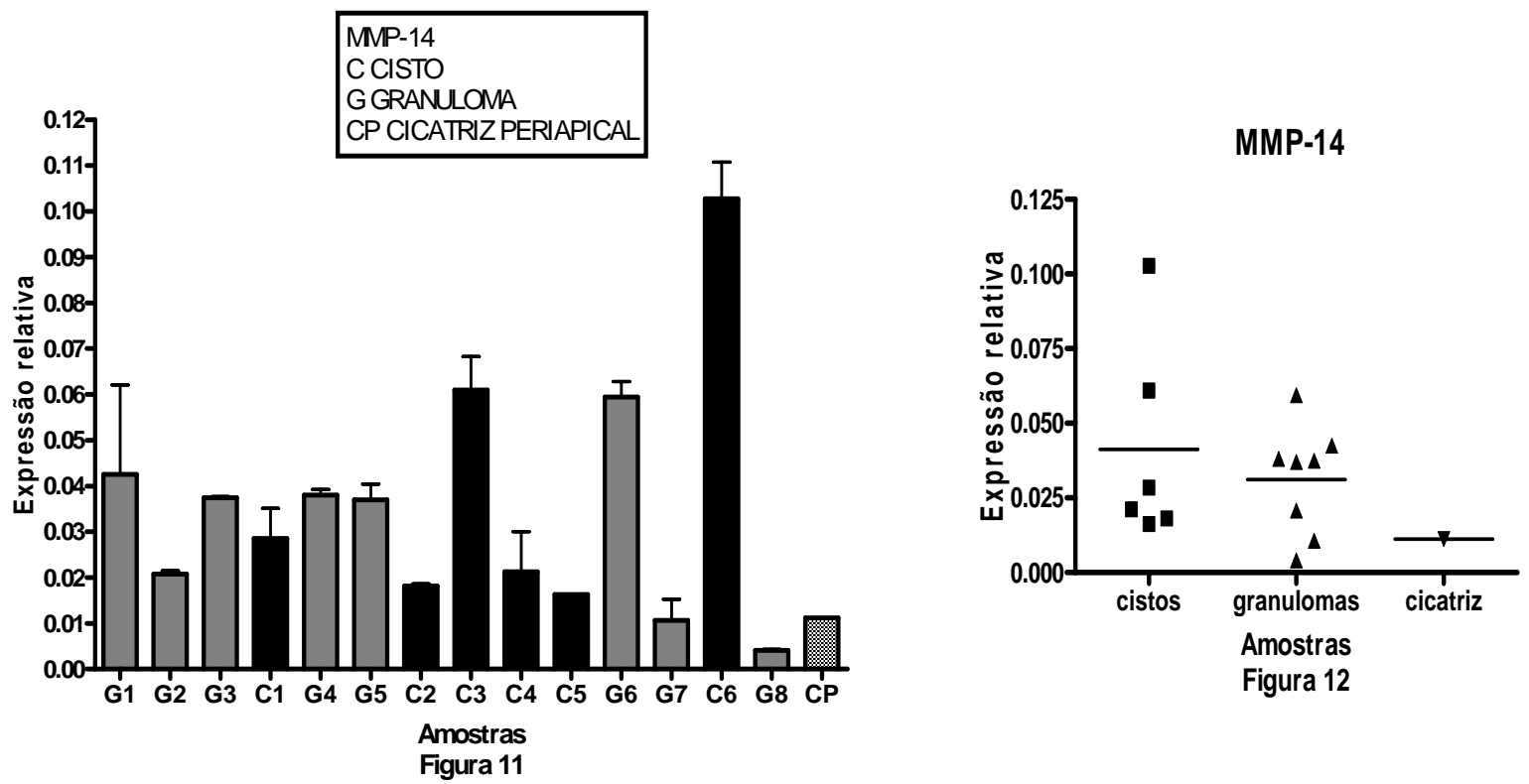

Figura 11: Níveis médios de expressão de MMP-14 entre granulomas, cistos e cicatriz periapicais. Figura 10: Níveis médios de expressão de MMP-14 nos grupos das amostras (gráfico de dispersão).

5.7Correlação entre a expressão de transcritos para MMP-2, -9 e -14 , TIMP-1, -2 e RECK

Os resultados para cada gene pesquisado não apresentaram significância estatística quando confrontados entre granulomas e cistos periapicais (teste "t"). Baseado nisso, correlacionou-se os resultados do grupo lesão periapical (dados das amostras de granulomas e cistos periapicais mediante a expressão de cada gene) entre os primers testados. Para isso, o 
teste de Pearson foi realizado com o auxílio do GraphPad Prism 3.0 software (GraphPad Software Inc, EUA) e valores considerados estatisticamente significantes foram identificados $(p<0,05)$ (Figura 13).

MMP-2 / TIMP-2

MMP-2 I RECK

MMP-2 / MMP-14

MMP-9 / TIMP-2

MMP-9 / MMP-14

TIMP-2 I RECK

TIMP-2 / MMP-14

MMP-2 / MMP-9

MMP-2 / TIMP-1

MMP-9 / TIMP-1

MMP-9 / RECK

TIMP-1 / TIMP-2

RECK / MMP-14

TIMP-1 / RECK

TIMP-1 / MMP-14
$P<0,0007$

$P<0,0011$

$P<0,0169$

$\mathrm{P}<0,0224$

$P<0,007$

$P<0,0005$

$\mathrm{P}<0,0004$

NS

NS

NS

NS

NS

NS

NS

NS

Figura 13: Correlações positivas e não significantes (NS). 
MMP-2 x TIMP-2

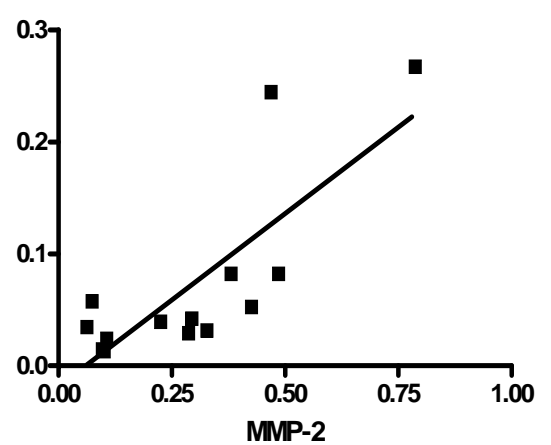

MMP-2 x MMP-14

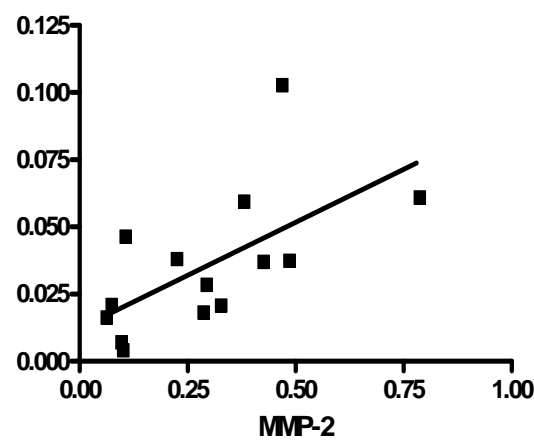

MMP-9 x MMP-14

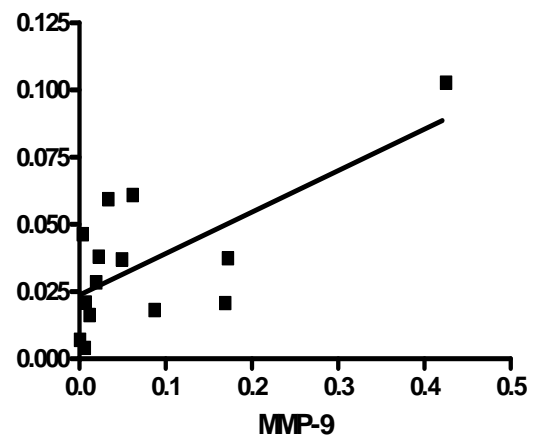

MMP-2 X RECK

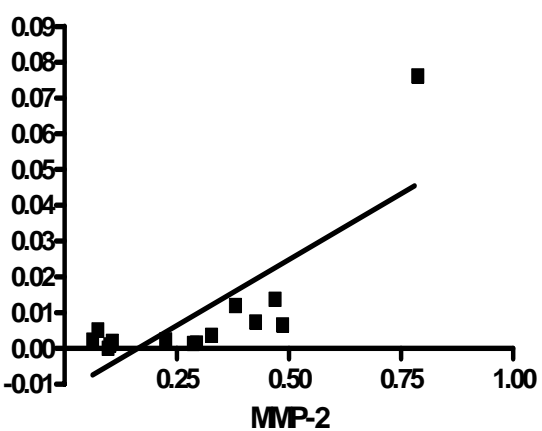

MMP-9 x TIMP-2

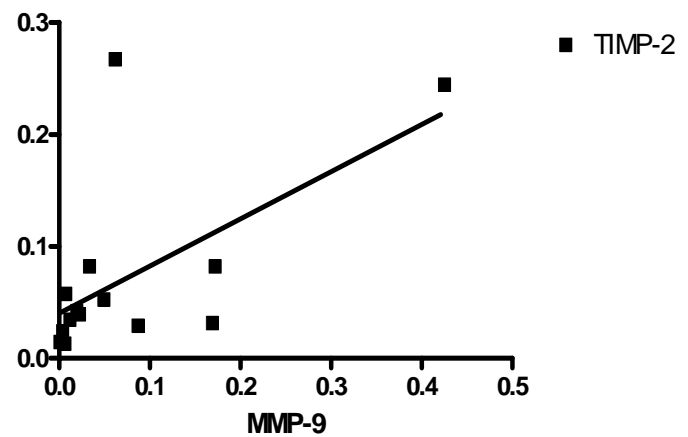

TIMP-2 x RECK

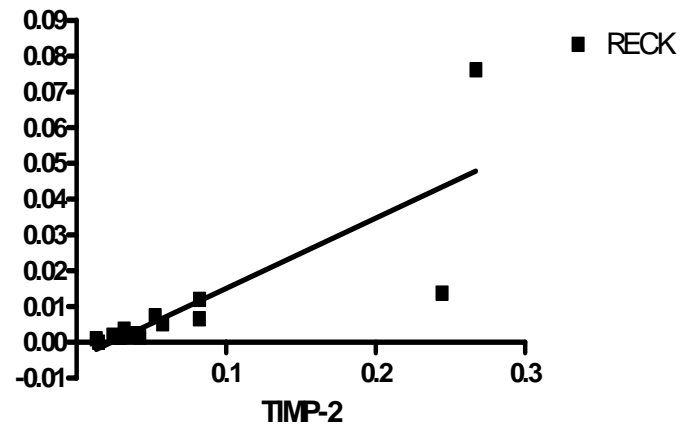

TIMP-2 x MMP-14

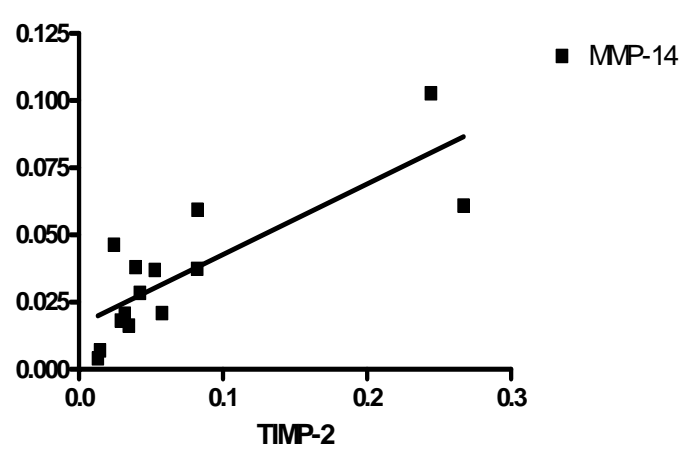

Figura 14: Seqüência gráfica de correlações positivas 


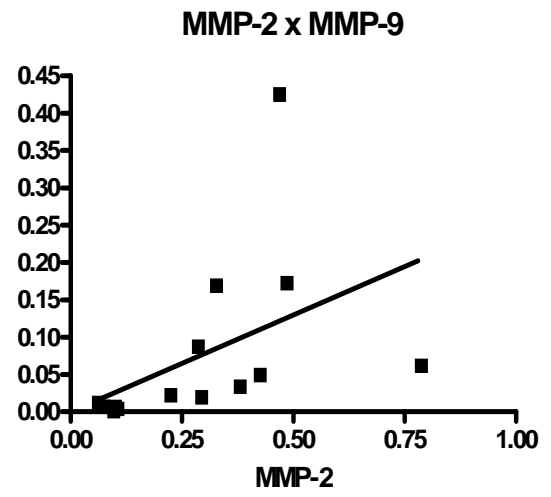

MMP-9 x TIMP-1

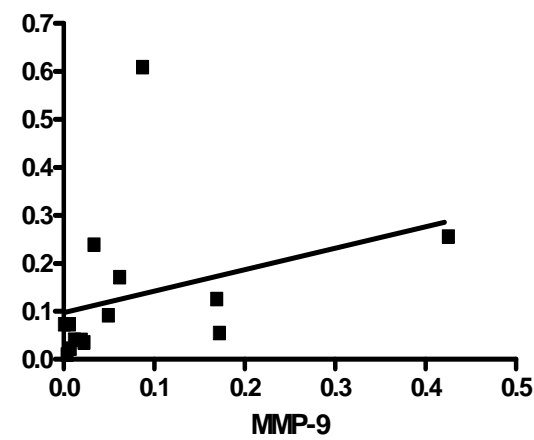

TIMP-1 x TIMP-2

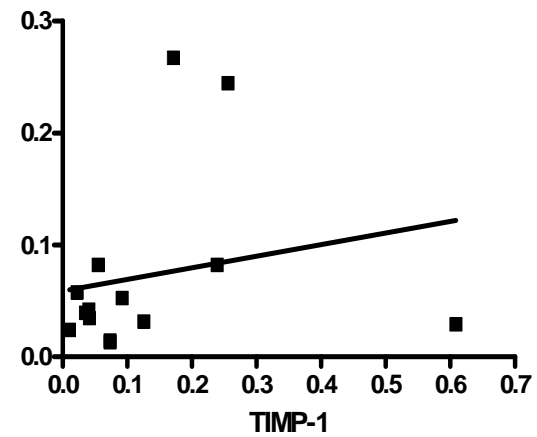

TIMP-1 x RECK

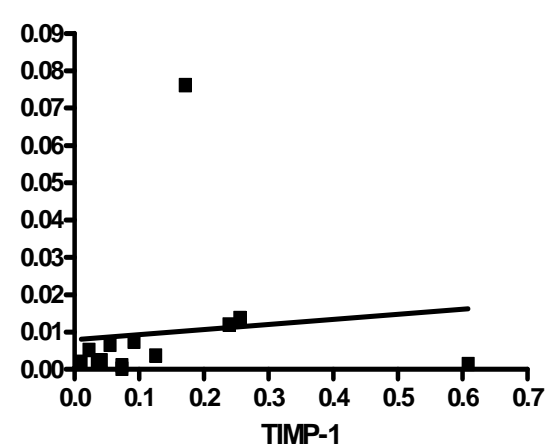

MMP-2 x TIMP-1

- MMP-9

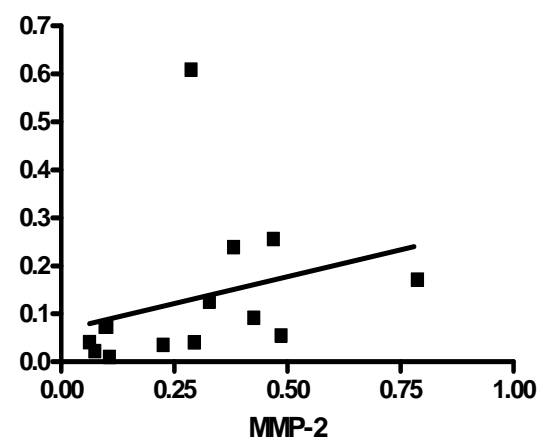

- TMP-1

MMP-9 x RECK

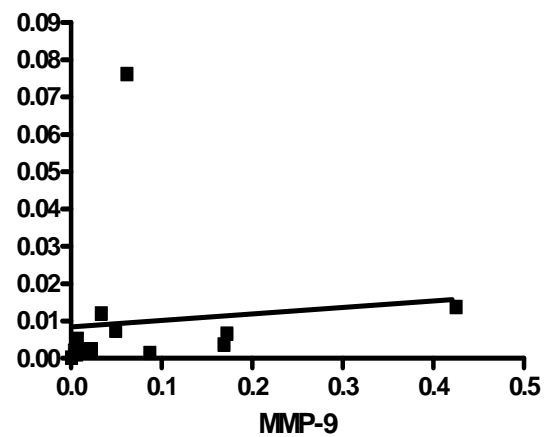

RECK x MMP-14

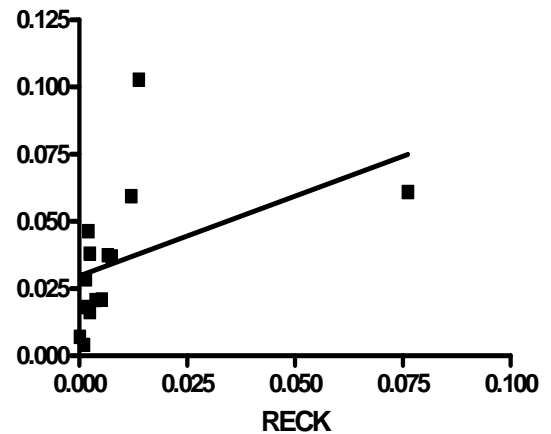

TIMP-1 x MMP-14

- RECK

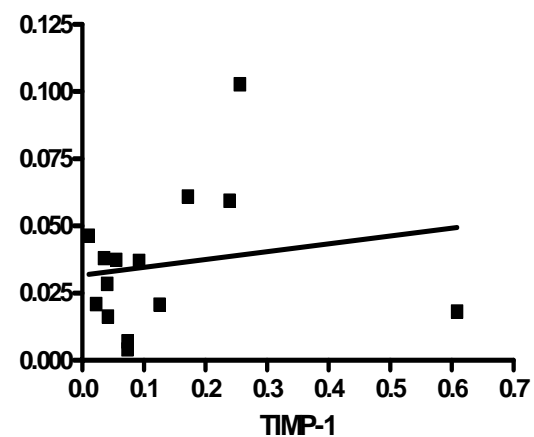

Figura 15: Seqüência gráfica de correlações não significantes. 


\subsection{Imunomarcação de MMP-2 e -9 para Granulomas periapicais}

As MMP-2 e -9 foram observadas abundantemente em células mononucleares, dispersas através no tecido de granulação das lesões periapicais. A MMP-2 foi expressa num padrão mais difuso, pericelular como também dispersas através da matriz extracelular, de acordo com as figuras 16A e 16B. A figura $16 \mathrm{C}$ foi o controle negativo. Por outro lado, a MMP-9 foi expressa num padrão mais localizado, tanto intra como pericelular, conforme demonstram as figuras 17D, 17E e 17F. A figura $17 \mathrm{G}$ corresponde ao controle negativo. Alguns polimorfonucleares neutrófilos expressaram MMP-9 (figura 17F).

A confirmação de essas células mononucleares serem macrófagos se deu por meio de imunomarcações de CD68+, conforme figuras $18 \mathrm{H}$ e 18I, sendo que a figura $18 \mathrm{~J}$ foi o controle negativo.
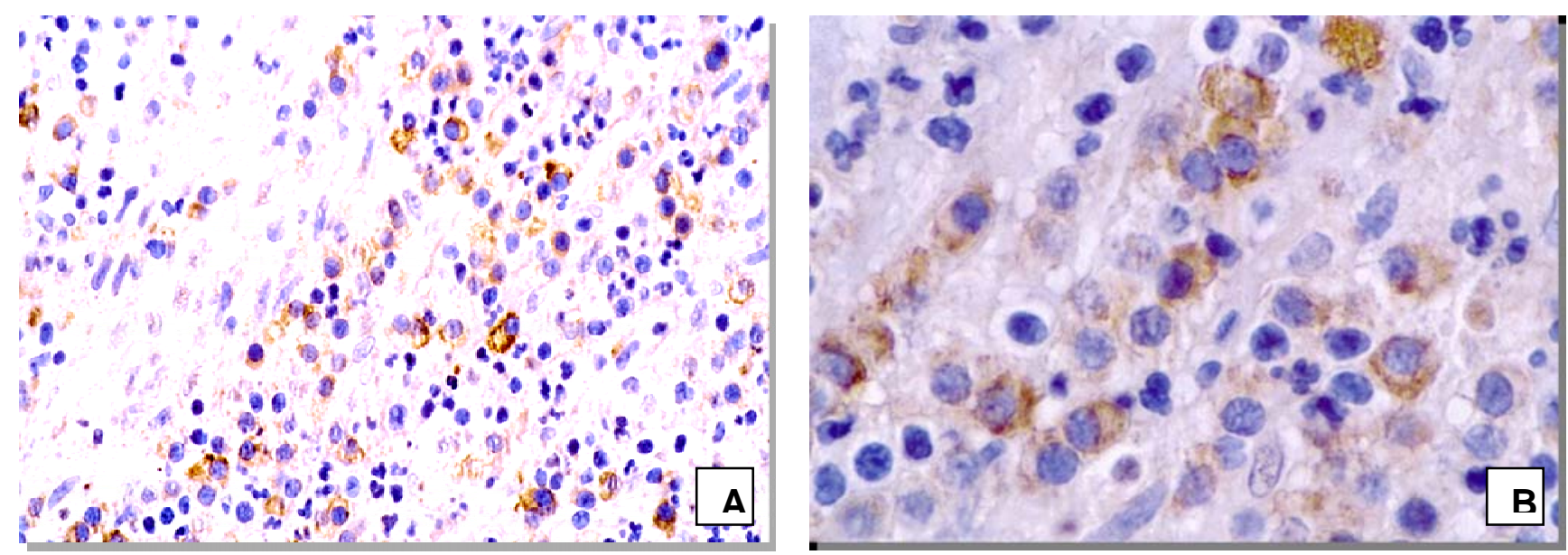

Figura 16: Imunomarcação para MMP-2 (A) 40X; (B) 100X. 


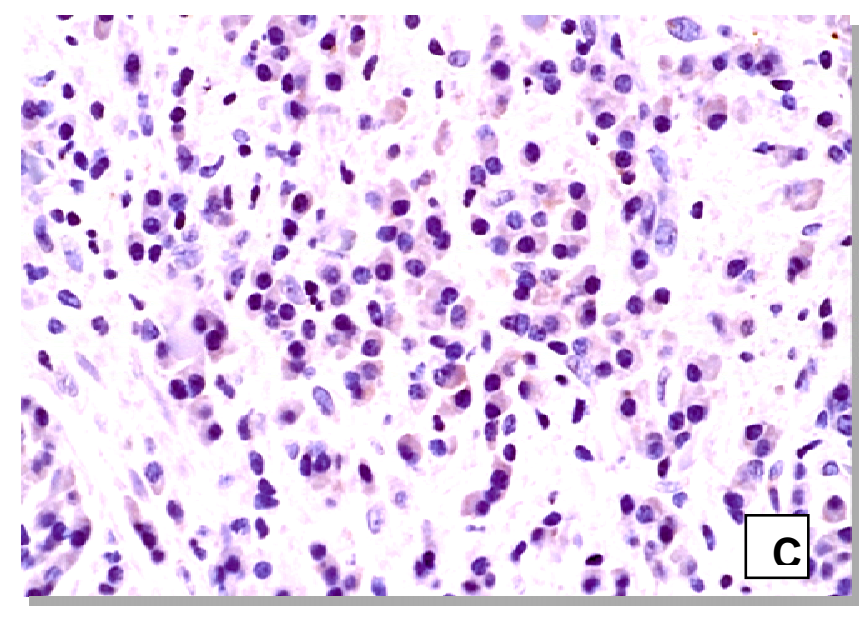

Figura 16: Imunomarcação para MMP-2 (C) 40X, Controle Negativo.
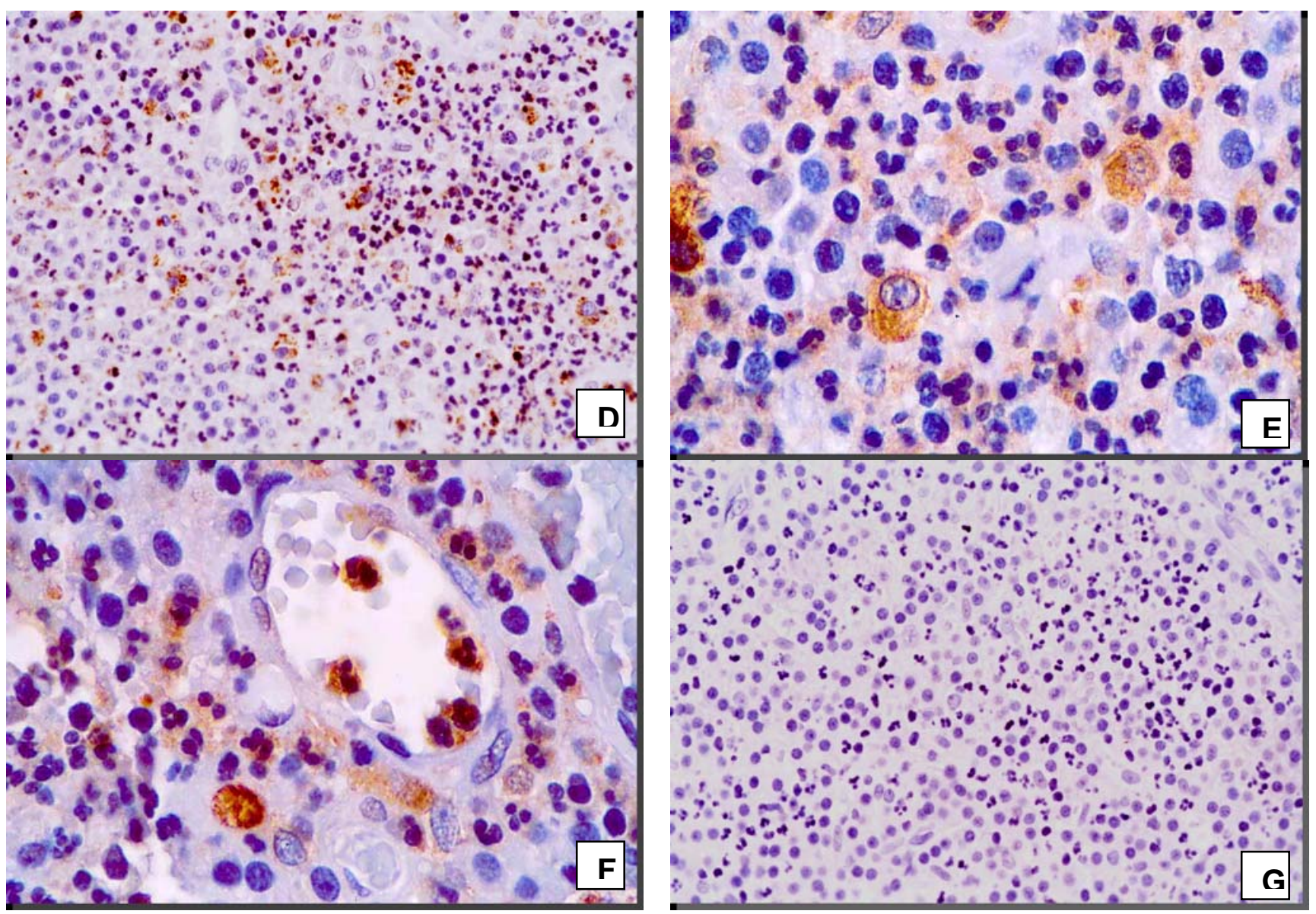

Figura 17: Imunomarcação para MMP-9 (D) 40X; (E , F) 100X; (G) 40X 

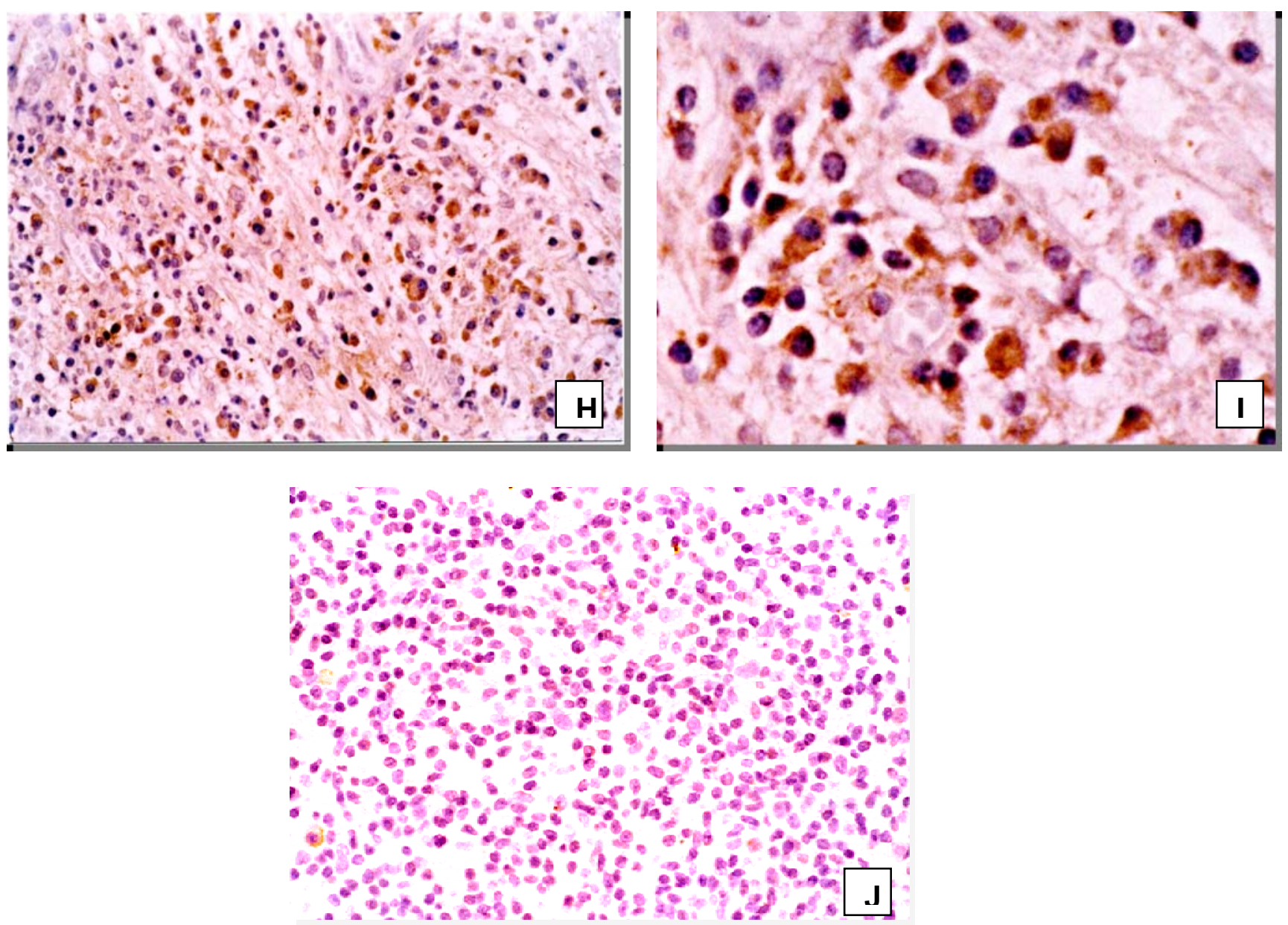

Figura 18: Imunomarcação para CD68+ (H) 40X; (I) 100X; (J) 40X 
DISCUSSÃO 


\section{DISCUSSÃO}

\subsection{Metodologia}

\subsubsection{Real Time PCR}

A reação em cadeia da polimerase (Polymerase Chain Reaction- PCR) é a amplificação enzimática de uma seqüência específica de DNA in vitro, visando a produção de milhões de cópias dessa seqüência. Essa técnica foi descrita por Kary Mullis, no final dos anos 80 , e tem revolucionado a genética molecular, pois possibilita uma nova estratégia na análise dos genes por meio de uma técnica de alta especificidade, alta sensibilidade e rapidez. ${ }^{12,13,26,49,74}$

A reação em cadeia de polimerase explora a capacidade de duplicação do DNA. Uma fita simples de DNA é usada como molde para a síntese de novas cadeias complementares sob a ação da enzima polimerase, capaz de adicionar os nucleotídeos presentes na reação, segundo a fita molde. A polimerase do DNA requer, entretanto, um "ponto de início" ligado à fita molde que servirá de apoio para que os nucleotídeos subseqüentes sejam adicionados. Esse ponto de início da síntese é fornecido por um oligonucleotídeo que se hibridiza (se anela) à fita molde simples, o qual é denominado de "primer". Ambas as fitas simples iniciais servem de fita molde para a síntese, desde que se forneçam "primers" específicos a cada uma delas. Dessa forma, a região do DNA genômico a ser sintetizada é definida pelos "primers", que se anelam especificamente às suas seqüências complementares na fita molde, delimitando o fragmento de DNA que se deseja amplificar. 
Na prática, o que se faz é adicionar, em um tubo de ensaio, uma quantidade muito pequena de DNA genômico, mais os quatro nucleotídeos que compõem a cadeia de DNA (dCTP, dATP, dGTP e dTTP), a enzima polimerase do DNA, os oligonucleotídeos que servirão de "primers" e a solução tampão, a qual fornecerá as condições de $\mathrm{pH}$ e salinidade para que a síntese se processe. Uma alta temperatura (geralmente 940C por 5 minutos) é necessária para provocar o rompimento das pontes de hidrogênio entre ambas as cadeias de DNA, causando a desnaturação da molécula. Em seguida, a temperatura é rebaixada (30 a $60{ }^{\circ} \mathrm{C}$ por 30 segundos) quando, então, os "primers" têm a oportunidade de se anelarem às suas seqüências complementares do DNA genômico. Finalmente, a temperatura é colocada em torno de $72{ }^{\circ} \mathrm{C}$ (por 2 a 5 minutos); essa temperatura é ideal para que a polimerase do DNA utilizada na reação atue, dirigindo a síntese de novas cadeias. Ao repetirem-se, esses três tipos de passos (desnaturação, anelamento e síntese), por cerca de 30 ciclos, produzirão mais de 250 milhões de cópias de uma determinada seqüência de DNA em fita dupla, uma vez que o número de cópias cresce de modo exponencial a cada ciclo. Após a primeira desnaturação do DNA genômico, o tempo de aquecimento a $94{ }^{\circ} \mathrm{C}$ pode ser reduzido para 30 segundos nos ciclos subseqüentes, tendo em vista que a renaturação da molécula será dificultada. 26

A reação em cadeia de polimerase quando parte do RNA é chamada de transcrição reversa (RT-PCR). Neste estudo, as lesões periapicais foram maceradas, e após lise tecidual e tratamento adequado, forneceram o RNA, do qual, verificada sua qualidade, foi sintetizado o cDNA. O Real Time RT-PCR 
permite a detecção e quantificação das seqüências gênicas (primers) em estruturas teciduais.

Desde a publicação da técnica do PCR, intensos são os estudos dessa em Medicina e Odontologia. A literatura odontológica relata diversos estudos dessa técnica, envolvendo a doença periodontal, cárie dentária, infecções endodônticas e câncer bucal. ${ }^{74}$

Utilizando-se de um estudo de Real Time RT-PCR, GARLET ${ }^{28}$ em 2004, procurou examinar os mecanismos pelos quais as citocinas TNF- $\alpha$, IFN-y, IL12, IL-4 e IL-10 modulam o curso da doença periodontal inflamatória num modelo experimental, em camundongos. Para a quantificação dos genes de citocinas e quimiocinas, assim como a quantificação da carga bacteriana no tecido periodontal, o autor utilizou também foi o sistema SYBERGreen no aparelho ABI5700 (Applied Biosystems, Warrington, Reino Unido).

Em Endodontia, BOGEN; SLOTS ${ }^{10}$ em 1999 estudaram usando a técnica do PCR, a prevalência de Porphyromonas endodontalis, P. gingivalis, $P$. intermédia e $P$. nigrescens em 20 lesões periapicais, todas essas cepas coletadas da região apical de tratamentos endodônticos que obtiveram insucesso, por meio de cirurgias parendodônticas. Os autores concluíram que bactérias anaeróbias, produtoras de pigmentos negros, parecem não constituir a maioria das bactérias em lesões chamadas refratárias e o seu baixo número nessas sugerem a relativa estabilidade e natureza crônica das patologias apicais.

A técnica do PCR foi utilizada também por SIQUEIRA JÚNIOR et al. ${ }^{79}$ em 2001, para verificar a ocorrência de cepas de bactérias produtoras de 
pigmentos negros em abcessos perirradiculares agudos. Nesse estudo foram utilizadas lesões de origem endodôntica (granulomas e cistos periapicais) obtidas de cirurgias paraendodônticas. Contudo, a utilização da técnica do Real Time RT-PCR não foi verificar microrganismos existentes em tais lesões, mas sim estudar a expressão de metaloprotease-2, -9 e -14, TIMP-1 e -2 e RECK, enzimas e proteínas relacionadas ao metabolismo da matriz extracelular, na tentativa de sugerir alguma relação que possa contribuir para um conhecimento mais profundo do processo evolutivo das lesões inflamatórias de origem endodôntica.

Contudo, nessa técnica de RT-PCR podem ocorrer erros, especialmente, quando as amostras são coletadas de diferentes indivíduos. Um método para minimizar estes erros e compensar as variações de amostra para amostra é a amplificação, simultaneamente, de um RNA conhecido, o qual servirá de controle interno, normalizando os valores. O ideal é que o controle endógeno deve ser expresso no mesmo nível do RNA da amostra a ser estudada. Os RNAs mais comumente utilizados são o GAPDH, $\beta$-actina e RNA ribossômicos. (Bustin AS, 2000).

PALOSSAARI et al. ${ }^{64}$ em 2003, trabalhando com cultura de células da polpa dental humana, estudaram a expressão relativa de várias MMPs, dentre elas MMP-2 e -9, aplicando a técnica do Real Time PCR, tendo como o controle endógeno o 18S RNA ribossômico. YANG et al. ${ }^{105}$ em 2002, utilizaram como controle a $\beta$-actina, para detectar os níveis de TIMP-1 na presença e ausência de IL-1a e TGF- $\beta$, em cultura de fibroblastos humanos. Em 2001, SATOYOSHI et al. ${ }^{76}$ se propuseram a detectar os níveis de expressão de 
MMP-2 e -9 na mineralização da matriz dentinária em cultura de células fibroblásticas, utilizando como controle o GAPDH. Sugeriram que o aumento dos níveis de expressão de MMP-2 no Real time PCR, em relação ao tempo, podem interferir no processo de mineralização dentinária, fato esse não observado para MMP-9.

No presente estudo, o controle endógeno, tanto para as MMPs, TIMPs e RECK, foi realizado com o gene GAPDH, utilizado em diversos estudos ${ }^{76,102}$ bem como no Instituto de Química da Universidade de São Paulo, onde realizou-se o Real Time RT-PCR, que utiliza o gene GAPDH rotineiramente, fazendo parte do protocolo de padronização dos resultados dos experimentos lá desenvolvidos. Todavia, existem estudos que questionam que os níveis do RNAm do GAPDH, que não são sempre constantes, indicando a $\beta$-actina como controle endógeno. ${ }^{12,28,49}$ Outros estudos experimentais indicam, ainda, que a normalização de amostras in vivo deve ser confrontada com o RNAr ou RNA total da amostra, não necessitando de um gene conhecido para o controle endógeno. ${ }^{13}$

A maior expressão do gene RECK possui correlação direta com a baixa invasividade e melhor prognóstico de câncer. Essa proteína regula negativamente a MMP-2, -9 e MMP-14. Estudos de RECK, com auxílio do Real-Time RT-PCR, têm demonstrado que sua expressão relativa aumenta na presença de tumores agressivos e seu índice de expressão é muito baixo nos tecidos normais. ${ }^{43,61,82}$ 


\subsubsection{Imuno-histoquímica}

O termo imuno-histoquímica surgiu da associação: imunologia, histologia e química. Tal termo compreende o processo de identificação de antígenos em secções de tecidos com o auxílio de anticorpos específicos. Na imuno-histoquímica, alguns conceitos devem ser revistos como o anticorpo monoclonal, que corresponde ao reconhecimento de um receptor ou um epítopo ou policlonal, reconhecimento de mais receptores ou epítopos. Os anticorpos utilizados neste estudo foram policlonais (MMP-2 e -9).

Os anticorpos policlonais diferem entre si, não só pelos determinantes antigênicos que são capazes de reconhecer, como também pela afinidade com que os mesmos são reconhecidos pelos antígenos, isto é, com que força ou intensidade ocorre a interação entre o antígeno e o anticorpo.

Para MMP-2 e -9, os anticorpos utilizados foram para MMP-2 (sc- 13595

- Santa Cruz Biotecnology Inc.), MMP-9 (sc 6840 - Santa Cruz Biotecnology Inc.) e CD68+ (SC-7082 Santa Cruz Biotecnology Inc.), todos diluídos na proporção de 1:100 em $0,1 \%$ PBS/BSA.). O processo de diluição é indicado pelo fabricante na sua bula (data-sheet).

Utilizou-se, como protocolo de imunomarcação, o método da imunoperoxidase, sugerido em vários estudos de imuno-histoquímica. ${ }^{27,} 40,42$, $47,72,89,95,99$

As amostras submetidas ao Real-Time RT-PCR demonstraram a expressão relativa dos níveis de transcritos para MMPs -2, -9 e -14, TIMP -1, -2 
e RECK encontradas nos tecidos das lesões periapicais coletados. Neste estudo, a imuno-histoquímica confirma os achados nos granulomas, pois identifica as populações celulares que estão expressando as MMPs -2 e -9 , por isso a importância da associação desses dois testes.

FURUMOTO et al. ${ }^{27}$ em 2001, associaram as duas metodologias já mencionadas para estudar a expressão do gene RECK em cânceres hepatocelular. A partir disso foi encontrado RNAm expresso em tecidos tumorais, quando se sabe que, nessas condições, sua expressão é reprimida durante a transformação celular; a imuno-histoquímica confirmou os achados do PCR, mostrando nesse mesmo tecido marcações no seu estroma. A expressão de RECK em cânceres pancreáticos, estudado por MASUl et al. ${ }^{47}$ em 2003, utilizando a imuno-histoquímica e a zimografia, sugeriu que quando o gene RECK é expresso, a atividade de MMP-2 não é inibida, ocorrendo, consequentemente, a invasão tumoral e a metástase.

SHIN et al. ${ }^{77}$ em 2002, associaram imuno-histoquímica e ELISA para verificação dos níveis de expressão de MMP-1, -2 e -3 em tecido pulpar e lesões periapicais. Além da imunolocalização, as concentrações de MMPs foram verificadas. Um fato interessante é que o teste ELISA forneceu ambas as formas, ativa e latente, das concentrações de MMP, verificando que elevadas concentrações nem sempre podem indicar, nesse tipo de teste, o estado de destruição tecidual. WAHLGREN et al. ${ }^{98}$ em 2002, analisaram os níveis de MMP-8 em polpa dental, em exsudatos e lesões periapicais, utilizando duas metodologias: Western blot e imuno-histoquímica. Com isso, verificaram que a presença de MMP-8 em polpas inflamadas e tecidos periapicais indica que 
essa enzima tem um papel na inflamação pulpar e periapical, participando da degradação da MEC, sugerindo, também, que a análise de MMP-8 no exsudato pode indicar e monitorar a atividade inflamatória.

Atualmente em pesquisa, há uma tendência de associar metodologias que possibilitam um maior número de testes para detectar e confirmar a expressão de uma determinada substância. A biologia molecular possui muitos recursos que, quando associados, garantem maior confiabilidade aos resultados obtidos.

\subsection{Resultados}

As lesões inflamatórias periapicais, granulomas e cistos radiculares representam dois diferentes estágios de desenvolvimento de uma resposta imunopatológica da estrutura apical. Esse processo inflamatório crônico caracterizado por um infiltrado persistente leva à reabsorção óssea e radicular. Os fatores que determinam a transformação cística estão presentes em alguns granulomas e todo mecanismo que envolve aquela transformação e posterior desenvolvimento é controverso. ${ }^{1,93,99}$

As metaloproteases da matriz (MMPs), responsáveis pela degradação da MEC, são expressas em níveis baixos nos tecidos normais, mas aumentadas durante o processo inflamatório. Por isso, em Odontologia, as MMPs vêm sendo amplamente estudadas em Periodontia e Endodontia. ${ }^{81,98}$

Os resultados do estudo em questão demonstraram que a imunohistoquímica de MMP-2 e -9 , para granuloma periapical, que células 
mononucleares dispersas pelo tecido de granulação se apresentaram imunomarcadas (Figura 16A, 16B, 17D, 17E e 17F). Imunomarcação para CD68+ mostrou que os macrófagos foram as principais células envolvidas na expressão dessas metaloproteases da matriz em todas as amostras examinadas (Figura 18I e 18J). As imunomarcações se apresentaram heterogêneas entre si, contudo tal fato pode ser justificado pelo resultado anatomopatológico, isto é, os granulomas periapicais demonstraram uma morfologia variada e diferente intensidade de componentes celulares. ${ }^{40}$ Tais variações aparecem por conta do estágio em que a lesão se apresenta. Granulomas com intenso infiltrado inflamatório do tipo linfohistioplasmocitário podem estar em fase evolutiva diferente de um outro granuloma com característica predominantemente fibroblástica e colagênica, tendo de permeio essas esparsas células inflamatórias.

É importante salientar, ainda, que há diferença na distribuição dos macrófagos nas lesões periapicais ${ }^{15}$. A maior concentração de células inflamatórias ocorre na região central dos granulomas periapicais, em

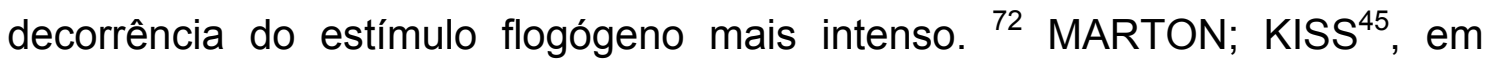
2000, corroboraram tal assertiva, afirmando que a maior concentração de células mononucleares ocorre na região central dos granulomas periapicais devido à proximidade do forame apical.

A expressão de MMP-2 em células inflamatórias e fibroblastos de granulomas e cistos periapicais foi observada por SHIN et al. ${ }^{77}$ em 2002 , contudo a expressão de MMP-1 e -3 foram mais intensas. 
A MMP-2, no presente experimento, apresentou um padrão mais difuso de imunomarcação, perifericamente às células e dispersa pela MEC, provavelmente pelo fato de aquela metaloprotease da matriz ser responsável pela ativação de outras enzimas, como a interação com TIMP-2 e MMP-14, que ocorre na superfície da membrana citoplasmática. ${ }^{59,70,75,100}$ Em comparação com a MMP-2, a MMP-9 apresentou um padrão mais localizado e restrito, sugerindo que essa MMP frequentemente é expressa em sítios ativos de destruição celular e de inflamação aguda, associada à polimorfonucleares neutrófilos. ${ }^{30,103}$

Os resultados oriundos do Real-Time PCR mostraram que houve a expressão de MMP-2, -9, -14, TIMP-1, -2, e RECK em granulomas e cistos periapicais, não havendo diferença, estatisticamente significante, entre as duas patologias periapicais frente aos genes testados.

A cicatriz periapical apresentou a expressão relativa de MMP-2 e -14 TIMP-1 e -2 e RECK superior ao apresentado em algumas amostras de granulomas e cistos periapicais, exceto para a MMP-9. Todavia, não mostrou nenhum pico de níveis de transcritos significativa. Isso, provavelmente, dá-se pela dinâmica envolvendo o remodelamento do tecido cicatricial que provoca a diminuição da sua matriz extracelular. 9, 30, 81, 103 Essa amostra de cicatriz periapical apresentou no exame anatomopatológico tecido bem colagenizado, áreas de depósito basofílico semelhantes a calcificações distróficas, com discreto infiltrado inflamatório mononuclear focal e disposição perivascular; foi anexada às amostras a fim de representar um controle negativo em relação aos processos patológicos inflamatórios pesquisados (granulomas e cistos 
periapicais). Contudo, os resultados demonstraram que sua expressão relativa não serve de controle conforme dito anteriormente. Esse fato reflete a dificuldade em estabelecer parâmetros de comparação nesse tipo de estudo, onde não se conhece o estágio da lesão coletada, pois todas provêm de cirurgias paraendodônticas; desse modo sendo diferente de estudos em lesões induzidas num modelo animal, que apresenta um quadro evolutivo conhecido. 28

A análise da diferença na quantificação dos níveis de transcritos de MMP-2, -9, -14, TIMP-1, -2 e RECK em lesões periapicais revelou uma expressão significativa de MMPs, TIMPs e RECK em todas as lesões estudadas.

As figuras de 1 a 12 mostram que a expressão relativa de MMP-2, -9 e 14 oscilaram entre granulomas e cistos periapicais, bem como o de seus inibidores, TIMP-1, -2 e RECK, não apresentando relação estatisticamente significante.

Um fato interessante observado é que numericamente a expressão relativa dos níveis de transcritos de RECK foi cerca de 10 vezes menor em relação à TIMP-1 e -2. Um exemplo é a amostra C3 que teve o maior pico dos níveis de transcritos de RECK, em torno de 0.065, em comparação à TIMP-1 e -2 , os níveis de transcritos para ambos os genes figuraram bem acima deste valor.

Quando o grupo lesão periapical (granuloma e cisto periapical) foi confrontado frente aos genes pesquisados, houve uma correlação significativa 
entre algumas expressões de transcritos para MMP-2, -9 e -14 , TIMP-1, -2 e RECK.

A MMP-2 apresentou correlação positiva com a TIMP-2 e MMP-14, ou seja, quando aumentou a expressão de MMP-2 na amostra pesquisada, os níveis de TIMP-2 e MMP-14 também se elevaram. Um dado importante deve ser mencionado, o fato da expressão de MMP-2 apresentar correlação positiva com TIMP-2, não significa que a primeira aumentou em função da segunda e sim que os níveis de transcritos de ambas apresentaram-se aumentados na amostra estudada. O Real Time RT-PCR quantifica os níveis de transcritos, não podendo ser confrontado com trabalhos na literatura que observam atividade enzimática ou protéica, pois em nosso estudo não temos a expressão da enzima (MMP-2, -9 e -14) e nem da proteína (TIMP-1, -2 e RECK) na sua forma ativa.

A ativação de algumas MMPs, como a MMP-2, requer a interação com certas MMPs que estão associadas à membrana citoplasmática, como a MMP14, a qual, por sua vez, cliva uma porção do prodomínio de MMP-2 para transformar sua forma latente em ativa 4, 70, 100 e também degrada vários componentes da matriz extracelular, incluindo o colágeno I. ${ }^{61}$

Um equilíbrio entre MMPs e TIMPS parece ser essencial para que não haja destruição tecidual. A MMP-9 ou gelatinase B é altamente produzida em processos inflamatórios agudos pulpares, ${ }^{30}$ visto que essa enzima é expressa por polimorfonucleares neutrófilos (PMN), macrófagos, queratinócitos e células endoteliais ${ }^{9}$ e sua produção não é constitutiva ${ }^{97}$, o que leva a crer que a sua 
ausência num tecido pulpar normal possa representar um indicador de polpa saudável. ${ }^{30}$

A MMP-9 apresentou correlação positiva com a TIMP-2 e com a MMP14. A MMP-9 tem seu nível de expressão controlado em resposta a citocinas e fatores de crescimento. A TIMP-2 tem uma alta afinidade com seus receptores, possuindo funções variadas conforme o tecido onde é expressa, inibindo a migração celular por meio da supressão da atividade de MMPs, principalmente a MMP-14, tendo a capacidade ainda de inibir a angiogênese. Em modelos de neoplasias malignas de colo retal, ela promove apoptose; contudo, em linhagens de células de melanoma, ela protege da apoptose. ${ }^{4}$ Neste estudo foi observada uma correlação positiva de TIMP-2 com MMP-2, -9, -14 e RECK. Somente com TIMP-1 houve uma correlação não significante.

Este é o primeiro estudo envolvendo RECK em lesões periapicais. Os resultados conseguidos nessa pesquisa demonstraram a presença dos níveis de transcritos nas amostras pesquisadas. É importante ressaltar que a presença da expressão de RECK no Real-time PCR não demonstra o quanto da enzima ou proteína será transcrita. Todavia, existem estudos que sugerem ser as TIMPs os maiores inibidores de MMPs, enquanto RECK parece ter uma atividade inibitória modesta. ${ }^{59}$ No estudo em tela, para ajudar a confirmar tal hipótese na amostra estudada, a imuno-histoquímica parece ser fundamental.

A localização de RECK e TIMPs são diferentes, ou seja, enquanto a primeira se encontra ancorada na membrana citoplasmática, as TIMPs são secretadas e difusas. A concentração de RECK na membrana plasmática 
proporciona uma efetiva regulagem dos eventos proteolíticos locais, que permeiam a superfície celular. ${ }^{47}$

Diversos estudos com neoplasias malignas envolvendo RECK, em tecidos tumorais, por ser um inibidor da MMP-2, -9 e 14, demonstram que a sua supressão determina aumento das MMPs. ${ }^{27,43,59,61,92}$ Desse modo, o melhor prognóstico em pacientes portadores de neoplasias malignas são aquelas que expressam RECK. ${ }^{27}$ Quando o sinal oncogênico é liberado, diminui-se a expressão de RECK e ocorre um aumento de MMP-9. ${ }^{92}$ Contudo, tem se observado uma forte ligação de RECK com MMP-2 e MMP-14. 43, 59, 100 Em contraste, MASUI et al. ${ }^{47}$ em 2003, afirmam que nenhuma correlação é estabelecida entre expressão de RECK e ativação de MMP-9.

O crescimento vascular é vital para que o desenvolvimento embrionário aconteça. Nessa fase, o equilíbrio dinâmico entre os componentes da MEC é necessário para que ocorra a angiogênese. A concentração inibitória de RECK sobre MMP-2, -9 e -14 é necessária perto de células endoteliais para que essas proliferem, possibilitando a ocorrência de neoformação de vasos sangüíneos. Estudos em camundongos que apresentam ausência de RECK, na sua fase embrionária, morrem no décimo dia, diferente de ausência de MMP-2, TIMP-1 e TIMP-2, que não apresenta influência no desenvolvimento embrionário. Por outro lado, quando MMP-14 é suprimida, os camundongos apresentam anormalidade óssea após o nascimento. ${ }^{59,61}$

Um complexo mecanismo molecular envolve a dinâmica do processo evolutivo de granulomas e cistos periapicais. Os níveis de expressão de MMP2, -9, -14, TIMP-1 e -2 e RECK e suas correlações positivas e não significantes 
variaram, provavelmente de acordo com o estágio evolutivo em que a lesão periapical se encontrava. Estudos futuros com MMPs e TIMPs serão importantes para ajudar a entender o processo de desenvolvimento das periodontites apicais crônicas. 


\section{CONCLUSÕES}




\section{CONCLUSÕES}

De acordo com a metodologia empregada, foi possível concluir:

1. Os níveis de transcritos para as enzimas (MMP-2, -9 e -14) e proteínas (TIMP-1, -2 e RECK) variou entre as amostras de granulomas e cistos periapicais estudadas;

2. A expressão relativa dos níveis de transcritos do gene RECK foi menor do que TIMP-1 e -2, quando comparados entre si na amostra estudada;

3. As imunomarcações nos granulomas periapicais para MMP-2 apresentou um padrão mais difuso em comparação com a MMP-9 que apresentou um padrão mais localizado e restrito;

4. Nas imunomarcações para MMP-2 e -9 , em granulomas periapicais, os macrófagos são as células que mais expressaram estas metaloproteases da matriz. 
REFERÊNCIAS BIBLIOGRÁFICAS 


\section{REFERÊNCIAS BIBLIOGRÁFICAS}

1 ALAVI, A.M.; GULABIVALA, K.; SPEIGHT, P.M. Quantitative analysis of lymphocytes and their subsets in periapical lesions. Int Endod J, v.31, n.4, p.233-41, Jul. 1998.

2 AUMAILLEY, M.; GAYRAUD, B. Structure and biological activity of the extracellular matrix. J Mol Med, v.76, n. (3-4), p.253-265, Mar.1998.

3 BAKER, E.A.; STEPHENSON, T.J.; REED, M.W.; BROWN, N.J. Expression of proteinases and inhibitors in human breast cancer progression and survival. Mol Pathol, v.55, n.5, p. 300-4, Oct. 2002.

4 BAKER, A.H.; EDWARDS, D.R.; MURPHY, G. Metalloproteinase inhibitors: biological actions and therapeutic opportunities. J Cell Sci, v.1, n.115 (Pt19), p. 3719-27, Oct. 2002.

5 BANDO, Y. Immunocytochemical localization of inflammatory cytokines and vascular adhesion receptors in radicular cysts. J. Oral Path. Med, v. 22, n. 5, p 221-7, May 1993.

6 BARKHORDAR, R. A.; DE SOUZA, Y. G. Human T-lymphocyte subpopulations in periapical lesions. Oral Surg Oral Med Oral Pathol, v. 65, n. 6, p. 763-6, Jun. 1988.

7 BAUER, E.A., STRICKLIN, G.P., JEFFREY, J.J., EISEN, A.Z. Collagenase production by human skin fibroblasts. Biochem 
Biophys Res Commun, v.64, n.1, p.232-40, May 1975.

8 BENAUD, C.; DICKISON, R.B.; THOMPSON, E.W. Roles of the matrix metalloproteinases in mammary gland development and cancer. Breast Cancer Res Treat, v.50, n.2, p.97-116, Jul. 1998.

9 BIRKEDAL-HANSEN, H. Role of matrix metalloproteinases in human periodontal diseases. J Periodontol, v. 64, n.5, p. 474-84, May 1993.

10 BOGEN, G.; SLOTS, J. Black-pigmented anaerobic rods in closed periapical lesions. Int Endod J, v.3, n.32, p.204-10, May 1999.

11 BRESLAUER, K.J.; FRANK, R.; BLOCKER, H.; MARKY, L.A. Predicting DNA duplex stability from the base sequence. Proc Natl Acad Sci USA, v.83, n.11, p. 3746-50, Jun. 1986.

12 BUSTIN, S.A. Absolute quantification of mRNA using real-time reverse transcription polymerase chain reaction assays. J Mol Endocrinol, v.25, n.2, p. 169-93, Oct. 2000.

13 BUSTIN, S.A. Quantification of mRNA using real-time reverse transcription PCR (RT-PCR): Trends and problems. J Mol Endocrinol, v.29, n.1, p. 23-39, Aug. 2002.

14 BYSTROM, A.; HAPPONEN R. P.; SJOGREN, U.; SUNDQVIST, G. Healing of periapical lesions of pulpless teeth after endodontic treatment with controlled asepsis. Endod Dent Traumatol, v.3, n.2, 
p. 58-66, Apr 1987.

CALLESTINI, R. Localização e distribuição de macrófagos identificados imunohistoquimicamente em cistos periodontais apicais de dentes tratados ou não endodonticamente. Contribuição para a compreensão da regressão não cirúrgica dos cistos periodontais apicais. Bauru, 1996. 97p. Dissertação (Mestrado) - Faculdade de Odontologia de Bauru, Universidade de São Paulo.

16 CHANG, C., WERB, Z. The many faces of metalloproteinases: cell growth, invasion, angiogenesis and metastases. TRENDS in Cell Biology, v.11, n.11, p. S37-43, Nov. 2001.

17 CHANG, Y.; LAI, C.; YANG, S.; CHAN, Y.; HSIEH, Y. Stimulation of matrix metalloproteinases by black-pigmented Bacteroides in human pulp and periodontal ligament cell cultures. J Endod, v.28, n.2, p. 90-93, Feb. 2002.

18 CHANG, Y.C.; YANG, S.F.; HSIEH, Y.S.; Regulation of matrix metalloproteinase-2 production by cytokines and pharmacological agents in human pulp cell cultures. J Endod, v. 27, n.11, p. 679-82, Nov. 2001.

19 CHAVEZ DE PAZ, L.E.; DAHLEN, G.; MOLANDER, A.; MOLLER, A.; BERGENHOLTZ, G. Bacteria recovered from teeth with apical periodontitis after antimicrobial endodontic treatment. Int Endod J, 
v.36, n.7, p.500-8, Jul. 2003.

20 CHIRGWIN, J.M.; PRZYBYLA, A.E.; MACDONALD, R.J.; RUTTER, W.J. Isolation of biologically active ribonucleic acid from sources enriched in ribonuclease. Biochemistry, v.27, n.18, p. 5294-9, Nov. 1979.

21 CONSOLARO, A.; RIBEIRO, C. F. Periapicopatias: etiopatogenia e inter-relações dos aspectos clínicos, radiográficos e microscópicos e suas aplicações terapêuticas. In: LEONARDO, M. R.; LEAL, J. M. Endodontia: tratamento de canais radiculares. Cap. 5, p. 76, 3 ed., São Paulo, Panamericana 1998.

22 COX, G.; O'BYRNE, K.J. Matrix metalloproteinase and cancer. Anticancer Res, v.21, n.6B, p. 4207-19, Nov/Dec. 2001.

23 CYMERMAN, J.J.; CYMERMAN, D.H.; WALTERS, J.; NEVINS, A.J. Human T lymphocyte subpopulations in chronic periapical lesions. J Endod, v. 10, n. 1, p. 9-11, Jan. 1984.

24 EGEBLAD, M.; WERB, Z. New functions for the matrix metalloproteinases in cancer progression. Nat Rev Cancer, v.2, n.3, p. 171-174, Mar. 2002.

25 ELLERBROEK, S.M.; STACK, M.S. Membrane associated matrix metalloproteinase in metastasis. Bioessays, v.21, n.11, p. 940-9, Nov. 1999. 
26 FARAH, S.B. DNA: segredos \& mistérios. São Paulo: Sarvier; 2000.

27 FURUMOTO, K.; ARII, S.; MORI, A.; FURUYAMA, H.; GORRIN RIVAS, M.J, NAKAO, T.; ISOBE, N.; MURATA, T.; TAKAHASHI, C.; NODA, M.; IMAMURA, M. RECK gene expression in hepatocellular carcinoma: correlation with invasion-related clinicopathological factors and its clinical significance. Reverse-inducing--cysteine-rich protein with Kazal motifs. Hepatology, v. 33, n.1, p.189-95, Jan. 2001.

28 GARLET, G.P. Participação de citocinas na imunomodulação da doença periodontal experimental induzida por Actinobacillus Actinomycetemcomitas. Ribeirão Preto, 2004, 183p. Tese (Doutorado) -Faculdade de Medicina de Ribeirão preto, Universidade de São Paulo.

29 GUIMARÃES, S. A. C. Patologia básica da cavidade bucal. Rio de Janeiro, Guanabara Koogan 1982.

30 GUSMAN, H.; SANTANA, R.B.; ZEHNDER, M. Matrix metalloproteinase levels and gelatinolytic in clinically healthy and inflamed human dental pulps. Eur J Oral Sci, v. 110, n. 5, p. 353-7, Oct. 2002.

31 HARPER, E., BLOCK, K.J., GROSS, J. The zymogen of tadplode collagenase. Biochemistry, v.10, n.16, p. 3035-3041, Aug. 1971.

32 HUANG, F.; YANG, S.; HSIEH, Y.; LIU, C.; YANG, L.; CHANG, Y. 
Examination of the signal transduction pathways involved in matrix metalloproteinases-2 in human pulp cells. Oral Surg Oral Med Oral Pathol Oral Radiol Endod, v.97, n.3, p. 398-403, Mar. 2004.

$33 \mathrm{ITOH}, \mathrm{Y}$; NAGASE, H. Matrix metalloproteinase in cancer. Essays Biochem, v.38, p. 21-36, 2002.

34 JONTELL, M, GUNRAJ, M.N, BERGENHOL,TZ G. Immunocompetent cells in the normal dental pulp. J Dent Res, v.66, n.6, p.1149-53, Jun. 1987.

35 KEUDELL, K.; POWELL, G.; BERRY, H. A review of microbial and immunologic aspects of endodontics. J Oral Med, v.36, n.2, p. 3943, Apr-Jun 1981.

36 KITAYAMA, H.; MATSUZAKI, T.; IKAWA, Y.; NODA, M. Genetic analysis of the Kirsten-ras-revertant 1 gene: potentiation of its tumor suppressor activity by specific point mutations. Proc Natl Acad Sci USA, v.87, n.11, p. 4284-8, Jun. 1990.

37 KONTIAINEN, S.; RANTA, H.; LAUTENSCHLAGER, I. Cells infiltrating human periapical inflammatory lesions. J Oral Pathol, v. 15, n, 10, p. 544-6, Nov. 1986.

38 KUNTZ D.D, GENCO R.J, GUTTUSO J, NATIELLA J.R. Localization of immunoglobulins and the third component of complement in dental periapical lesions. J Endod, v.3, n.2, p.68-73, Feb. 1977. 
LEKANNE DEPREZ, R.H.; FIJNVANDRAAT, A.C.; RUIJTER, J.M.; MOORMAN, A.F. Sensitivity and accuracy of quantitative real-time polymerase chain reaction using SYBR green I depend on cDNA synthesis conditions. Anal Biochem, v.1, n. 307, p. 63-9, Aug. 2002.

40 LEONARDI, R.; CALTABIANO, R.; LORETO, C. Collagenase-3 (MMP13) is expressed in periapical lesions: na immunohistochemical study. Int Endod J, v.38, n.5, p.297-301, May 2005.

41 LEONARDO, M. R.; LEAL, J. M. Endodontia: tratamento de canais radiculares. 3 ed. , São Paulo, Panamericana 1998.

42 LIN, S.K.; CHIANG, C.P.; HONG, C.Y.; LIN, C.P.; LAN, W.H.; HSIEH, C.C.; KUO, M.Y. Immunolocalization of interstitial collagenase (MMP-1) and tissue inhibitor of metalloproteinases-1 (TIMP-1) in radicular cysts. J Oral Pathol Med, V.26, n.10, p. 458-63, Nov 1997.

43 LIU, L.T.; CHANG, L.C.; CHIANG, L.C.; HUNG, W.C. Histone deacetylase up-regulates RECK to inhibit activation and cancer cell invasion. Cancer Res, v. 15, n. 63, p. 3069-72, June 2003.

44 MÁRTON, I. J.; KISS, C. Characterization of inflammatory cell infiltrate in dental periapical lesions. Int Endod J, v. 6, n. 2, p. 131-6, Mar. 1993. 
MÁRTON, I.J.; KISS, C. Protective and destructive immune reactions in apical periodontitis. Oral Microbiol Immunol, v.15, n.3, p.139-50, Jun. 2000.

MASSOVA, I.; KOTRA, L.P.; FRIDMAN, R.; MOBASHERY, S. Matrix metalloproteinase: structures, evolution and diversification. FASEB, v.12, n.12, p. 1075-95, Sep. 1998.

47 MASUI, T.; DOI, R.; KOSHIBA, T.; FUJIMOTO, K. ; TSUJI, S.; NAKAJIMA, S.; KOIZUMI, M.; TOYODA, E.; TULACHAN, S.; ITO, D.; KAMI, K.; MORI, T.; WADA, M.; NODA, M.; IMAMURA, M. RECK expression in pancreatic cancer: its correlation with lower invasiveness and better prognosis. Clin Cancer Res, v.9, n 5, p.1779-84, May 2003.

48 MATSUO, T.; NAKANISHI, T.; EBISU, S. Immunoglobulins in periapical exudates of infected root canals: correlations with the clinical findings of the involved teeth. Endod Dent Traumatol, v.11, n.2, p.95-9, Apr 1995.

49 MOCELLIN, S.; ROSSI, C.R.; PILATI, P.; NITTI, D.; MARINCOLA, F.M. Quantitative real-time PCR: a powerful ally in cancer research. TRENDS in molecular Medicine, v.9, n.5, p.189-95, May 2003.

50 MÖLLER, A. J.; FABRICIUS, L.; DAHLEN, G.; SUNDQVIST, G.; HAPPONEN, R. P. Apical periodontitis development and bacterial response to endodontic treatment. Experimental root canal 
infections in monkeys with selected bacterial strains. Eur J Oral Sci, v.112, n.3, p.207-15, Jun 2004.

51 MORSE, D.R. LASATER, D.R, WHITE, D. Presence of immunoglobulinproducing cells in periapical lesions. J Endod, v.1, n.10, p.338-343, Oct. 1975.

52 MORTON, T.H, CLAGETT J.A, YAVORSKY J.D.; Role of immune complexes in human periapical periodontitis. J Endod, v.3, n.7, p.261-268, Jul. 1977.

53 MYSLIWIEC, A.G.; ORNSTEIN, D.L. Matrix metalloproteinase in colorectal cancer. Clin Colorectal Cancer, v.1, n.4, p. 208-19, Feb. 2002.

54 NAGASE, H.; WOESSNER, J.F. Matrix metalloproteinases. J Biol Chem, v.274, n.34, p. 21491-4, Jul. 1999.

55 NAIR, P.N, SJOGREN, U, KREY, G, SUNDQVIST, G. Therapy-resistant foreign body giant cell granuloma at the periapex of a root-filled human tooth. J Endod, v.16, n.12, p.589-95, Dec.1990.

56 NAKATA, K.; YAMASAKI, M.; IWATA, T.; SUZUKI, K.; NEKANE, A.; NAKAMURA, H. Anaerobic bacterial extracts influence production of matrix metalloproteinase and their inhibitors human dental pulp cells. J Endod, v. 26, n. 7, p.410-3, Jul. 2000.

57 NODA, M. Mechanism of reversion. FASEB, v.7, n.10, p. 834-40, Jul. 
1993.

58 NODA, M.; KITAYAMA, H.; MATSUZAKI, T.; SUGIMOTO, Y.; OKAYAMA, H.; BASSIN, R.H.; IKAWA, Y. Detection of genes with a potential for suppressing the transformed phenotype with activade ras genes. Proc Natl Acad Sci USA, v.86, n.1, p.162-6, Jan. 1989.

59 NODA, M.; OH, J.; TAKAHASHI, R.; KONDO, S.; KITAYAMA, H.; TAKAHASHI, C. RECK: A novel suppressor of malignancy linking oncogenic signaling to extracellular matrix remodeling. Cancer Metastasis Rev, v.22, n.2-3, p.167-75, Jun-Sep. 2003.

60 O'BOSKEY, J.F.Jr., PANAGAKOS, F.S. Cytokines stimulate matrix metalloproteinase production by human pulp cells during long-term culture. J Endod, v. 24, n.1, p. 7-10, Jan. 1998.

$61 \mathrm{OH}$, J.; TAKAHASHI, R.; KONDO, S.; MIZOGUCHI, A.; ADACHI, E.; SASHARARA, R.M.; NISHIMURA, S.; IMAMURA, Y.; KITAYAMA, H.; ALEXANDER, D.B.; IDE, C.; HORAN, T.P.; ARAKAWA, T.; YOSHIDA, H.; NISHIKAWA, S.; ITOH, Y.; SEIKI, M.; ITOHARA, S.; TAKAHASHI, C.; NODA, M. The membrane -anchored MMP inhibitor RECK is a key regulator of extracellular matrix integrity and angiogenesis. Cell, v.107, n.6, p. 789-800, Dec. 2001.

62 OKIJI, T.; KAWASHIMA, N.; KOSAKA T.; MATSUMOTO, A.; KOBAYASHI, C.; SUDA, H. An immunohistochemical study of the distribution of immunocompetent cells, especially macrophages and 
la antigen-expressing cells of heterogeneous populations, in normal rat molar pulp. J Dent Res, v. 71, n.5, p.1196-202, May 1992.

63 ORSTAVIK, D.; NORDAHL, I.; TIBBALLS, J.E. Dimensional change following setting of root canal sealer materials. Dent Mater, v.17, n.6, p. 512-9, Nov 2001.

64 PALOSSAARI, H.; PENNINGTON, C.J.; LARMAS, M.; EDWARDS, D.R.; TJARDERHANE, L.; SALO, H. Expressions profile of matrix metalloproteinase (MMPs) and tissue inhibitors of MMPs in mature human odontoblasts and pulp tissue. Eur J Oral Sci, v.111, n.2, p.117-27, Apr. 2003.

PIATTElli, A.; ARTESE, L.; ROSINI, S.; QUARANTA, M.; MUSIANI, P. Immune cells in periapical granuloma: morphological and immunohistochemical characterization. J Endod, v. 17, n. 1, p. 269, Jan. 1991.

66 PULVER, W.H, TAUBMAN M.A, SMITH D.J. Immune components in normal and inflamed human dental pulp. Arch. Oral Biol, v.22, n.2, p.103-11, 1977.

67 PUPA, S.M.; MENARD, S.; FORTI, S.; TAGLIABUE, E. New insights into the role of extracellular matrix during tumor onset and progression. J Cell Physiol, v.192, n.3, p. 259-67, Sep. 2002.

68 RABBANI, S.A.; HARAKIDAS, P.; GUO, Y.; STEINMAN, D.; 
DAVIDSEN, S.K.; MORGAN, D.W. Synthetic inhibitor of matrix metalloproteinase decreases tumor growth and metastases in a syngeneic model of rat prostate cancer in vivo. Int J Cancer, v.87, n.20, p. 276-82, Jul. 2000.

69 RAMIREZ, F \& RIFKIN, D.B. Cell signaling events: a view from the matrix. Matrix Biology, v.22, n.2, p. 101-107, Apr. 2003.

70 RHEE, J.S.; COUSSENS, L.M. RECKing MMP function: implications for cancer development. Trends Cell Biol, v.12, n.5, p. 209-11, May 2002.

71 ROCHA, M. J. C. Estudo microscópico e imunohistoquímico dos cistos periodontais apicais de dentes tratados ou não endodonticamente. Sua relação com a regressão não cirúrgica. Bauru, 1991. 152p. Tese (Doutorado) - Faculdade de Odontologia de Bauru, Universidade de São Paulo.

72 RODINI, C.O.; LARA, V.S. Study of the expressions of CD68 macrophages and CD8 T cells in human granulomas and periapical cysts. Oral Surg Oral Med Oral Pathol Oral Radiol Endod, v.92, n. 2, p. 221-27, Aug. 2001.

73 ROSKELLEY, C.D.; BISSEL, M.J. The dominance of the microenvironment in the breast and ovarian cancer. Semin Cancer Biol, v.12, n.2, p. 97-104, Apr. 2002. 
SANTOS, C.F.; SAKAI, V.T.; MACHADO, M.A.A.M.; SCHIPPERS, D.N.; GREENE, A.S. Reverse transcription and polymerase chain reaction: principles and applications in dentistry. J Appl Oral Sci, v.12, n.1, p.1-11, Jan/Mar. 2004.

SASAHARA, R.M.; BROCHADO, S.M.; TAKAHASHI, C.; OH J.; MARIAENGLER, S.S.; GRANJEIRO, J.M.; NODA, M.; SOGAYAR, M.C. Transcriptional control of the RECK metastasis/angiogenesis suppressor gene. Cancer Detect Prev, v.26, n. 6, p.435-43, 2002.

76 SATOYOSHI, M.; KAWATA, A.; KOIZUMI, T.; INOUE, K.; ITOHARA, S.; TERANAKA, T.; MIKUNI-TAKAGAKI, Y. Matrix metalloproteinase-2 in dentin matrix mineralization. J Endod, v.27, n.7, p. 462-6, July 2001.

77 SHIN, S.J.; LEE, J.L.; BAEK, S.H.; LIM, S.S. Tissue levels of matrix metalloproteinase in pulps and periapical lesions. J Endod, v.28, n. 4, p.313-315, Apr. 2002.

78 SINGER, C.F.; KRONSTEINER, N.; MARTON, E.; KUBISTA, M.; CULLEN, K.J.; HIRTENLEHNER, K.; SEIFERT, M.; KUBISTA, E. MMP-2 and MMP-9 expression in breast cancer-derived human fibroblast in differentially regulated by stromal-epithelial interactions. Breast Cancer Res Treat, v.72, n.1, p. 69-77, Mar. 2002.

79 SIQUEIRA JÚNIOR, J.F.; ROCAS, I.N.; OLIVEIRA, J.C.; SANTOS K.R. Detection of putative oral pathogens in acute periradicular abcesses 
by $16 \mathrm{~S}$ rDNA-directed polymerase chain reaction. J Endod, v.27, n.3, p.164-7, Mar, 2001.

80 SOL, M.A.; TKACZUK, J. ; VOIGT, J.J.; DU RAND, M. ; SIXOU, M.; MAURETTE, A.; THOMSEN, M. Characterization of lymphocyte subpopulations in periapical lesions by flow cytometry. Oral Microbiol Immunol, v. 13, n. 4, p. 253-8, Aug. 1998.

81 SOUZA, A, P.; LINE, S, R, P. The biology of matrix metalloproteinases. J Appl Oral Sci, v.10, 1, p.1-6, Jan/Mar. 2002.

82 SPAN, P.N.; SWEEP, C.G.J.; MANDERS, P.; BEEX, L.V.A.M.; LEPPERT, D.; LINBERG, R.L.P. Matrix metalloproteinase inhibitor reversion-inducing cysteine-rich protein with Kazal motifs: a prognostic maker for a good clinical outcome in human breast carcinoma. Cancer, v.97, n.11, p. 2710-15, Jun. 2003.

83 STERN, M.H.; DREIZEN, S.; MACKLER, B. F.; LEVY, B. M. Antibodyproducing cells in human periapical granulomas and cysts. $\mathbf{J}$ Endod, v.7, n.10, p.447-52, Oct 1981.

84 STERNLICHT, M.D.; COUSSENS, L.M.; VU, T.H.; WERB, Z. Biology and regulation of the matrix metalloproteinases. Matrix Metalloproteinase. Inhibitors in Cancer Therapy, ed. NJ Clendeninn, K Appelt, p.1-37. Totowa, NJ: Humana, 2001.

85 STERNLICHT, M.D.; WERB, Z. ECM proteinases. Guidebook to the 
Extracelular Matrix, Anchor and Adhesion Proteins, ed. T Kreis, R Vale, p.503-562. Oxford, UK: Oxford Univ Press, 1999.

STERNLICHT, M.D.; WERB, Z. How matrix metalloproteinases regulate cell behavior. Annu Rev Cell Dev Biol, v.17, p. 463-516, 2001.

87 STOCKER, W.; GRAMS, F.; BAUMANN, U.; REINEMER, P.; GOMISRUTH, F.X.; MCKAY, D.B.; BODE, W. The metzincins - topological and sequential relations between the astacin, adamalysin, seralysin and matrix (collagenases) define a superfamily of zinc-peptidases. Protein Sci, v.4, n.5, p.823-840, May 1995.

88 SUNDQVIST, G. Association between microbial species in dental root canal infections. Oral Microbiol. Immunol., v. 7, n. 5, p 257-62, Oct. 1992.

89 SUZUKI, T.; KUMAMOTO, H.; OOYA, K.; MOTEGI, K. Expression of inducible nitric oxide synthase and heat shock proteins in periapical inflammatory lesions. J Oral Pathol Med, v.31, n.8, p.488-93, Sept 2002.

90 SZE-KWAN, L.; SANG-HENG K.; YEN-PING K, TZU-JOU W, JENGTZUUNG W, TZU-CHIN Y.F.; HSIAO M.; WAN-HONG, L.; CHIYANG H. Sequential expressions of MMP-1, TIMP-1, IL-6 and COX2 genes in induced periapical lesions in rats. Eur J Oral Sci, v.110, n.3, p. 246-53, Jun. 2002. 
91 TAKAHASHI, C.; AKIYAMA, N.; MATSUZAKI, T.; TAKAI, S.; KITAYAMA, H.; NODA, M. Characterization of a human MSX-2 cDNA and its fragment isolated as a transformation suppressor gene against v-ki-ras oncogene. Oncogene, v.12, n.10, p. 2137-46, May 1996.

92 TAKAHASHI, C.; SHENG, Z.; HORAN, T.P.; KITAYAMA, H.; MAKI, M.; HITOMI, K.; KITAURA, Y.; TAKAI, S.; SASHARARA, R.M.; HORIMOTO, A.; IKAWA, Y.; RATZKIN, B.J.; ARAKAWA, T.; NODA, M. Regulation of matrix metalloproteinase- 9 and inhibition of tumor invasion by the membrane-anchored glycoprotein RECK. Proc Natl Acad Sci USA, v.95, n.22, p.13221-6, Oct. 1998.

93 TAKAHASHI, K. Microbiological, pathological, inflammatory, immunological and molecular biological aspects of periradicular disease. Int Endod J, v.31, n.5, p. 311-25, Sep. 1998.

94 TAKAHASHI, K, LAPPIN, D.F, MACDONALD, G.D, KINANE, D.F.; Relative distribution of plasma cells expressing immunoglobulin G subclass mRNA in human dental periapical lesions using in situ hybridization. J Endod, v. 24, n.3, p.164-7, Mar. 1998.

95 TAKEICHI, O.; HAYASHI, M.; TSURUMACHI, T.; TOMITA, T.; OGIHARA, H.; OGISO, B.; SAITO, T. Inducible nitric oxide synthase activity by interferon-gamma-producing cells in human radicular cysts. Int Endod J, v.32, n2, p.124-30, Mar 1999. 
TJADERHANE, L.; LARJAVA, H.; SORSA, T.; UITTO, V,J.; LARMAS, M.; SALO, T. The activation and function of host matrix metalloproteinases in dentin matrix breakdown in caries lesions. J Dent Res, v.77, n.8, p.1622-9, Aug. 1998.

97 VU, T.H. Don't mess with the matrix. Nat Genet, v.28, n.3, p. 202-3, Jul. 2001.

98 WAHLGREN, J.; SALO, T.; TERONEN, O.; LUOTO, H.; SOROSA, T.; TJADERHANE, T. Matrix metalloproteinase-8 (MMP-8) in pulp and periapical inflammation and periapical root canal exudates. Int Endod J, v.35, n.11, p. 897-904, Nov.2002.

99 WALKER, K.F.; LSPPIN, D.F.; TQAKAHASHI, K.; HOPE, J.; MACDONALD, D.G.; KIANAME, D.F. Cytokine expression in periapical granulation tissue as assessed by immunohistochemistry. Eur J Oral Sci, v. 108, n.3, p. 195-201, Jun. 2000.

100 WELM, B.; MOTT, J.; WERB, Z. Developmental biology: vasculogenesis is a wreck without RECK. Curr Biol, v.19, n.12, p.209-11, Mar 2002.

101 WERB, Z., ASHKENAS, J., MACAULEY, A., WIESEN, J.F. Extracelular matrix remodeling as a regulator of stroma-epithelial interactions during mammary gland development. Braz J Med Biol Res, v.29, n.9, p.1087-97, Sep. 1996.

102 WINER, J.; JUNG, C.K.; SHACKEL, I.; WILLIANS, P.M. Development 
and validation of real-time quantitative reverse transcriptasepolymerase chain reaction for monitoring gene expression in cardiac myocytes in vitro. Anal Biochem, v.270, n.1, p.41-9, May 1999.

103 WOESSNER, J.F.; NAGASE, H. Matrix Metalloproteinases and TIMPs. 1 ed., New York, Oxford University Press 2000.

104 YANAGISAWA S. Pathologic study of periapical lesions 1. Periapical granulomas: clinical, histopathologic and immunohistopathologic studies. J Oral Pathol, v.9, n. 5, p.288-300, Sep 1980.

105 YANG, Y.Y.; TSAI, H.F.; LU, S.C.; HUANG, Y.F.; CHANG, Y.C. Regulation of tissue inhibitors of metalloproteinase-1 gene expression by cytokines in human gingival fibroblasts. J Endod, v.28, n.12, p. 803-5, Dec. 2002.

106 YU, Q., STAMENKOVIC, L. Cell surface-localized matrix metalloproteinase- 9 proteolytically activates TGF- $\beta$ and promotes tumor invasion and angiogenesis. Genes Dev, v.14, n.2, p.163-76, Jan. 2000.

107 YU, S.M.; STASHENKO, P. Identification of inflammatory cells in developing rat periapical lesions. J Endod, v. 13, n. 11, p. 535-40, Nov. 1987.

108 ZACHRISSON, B.U. Mast cells in human dental pulp. Arch. Oral Biol, v.16, n.5, p.555-6, May 1971. 


\section{ABSTRACT}




\section{ABSTRACT}

Degradation of extracellular matrix (ECM) proteins by matrix metalloproteinases (MMPs) occurs during matrix turnover and pathologic processes (inflammation, cancers). MMP activity in the tissues is regulated in part by a group of tissue inhibitors (TIMPS). Recently, a new MMP inhibitor called RECK (reversion inducing cysteine-rich protein with a Kazal motif) has been identified. In this study, we verified the message (mRNA) for MMPs (MMP-2, -9 e -14), tissue inhibitors of metalloproteinases (TIMP-1 e -2) and RECK, through a Real-Time RT-PCR technique, as well as the cells expressing MMP-2 and -9 in periapical granulomas using immunohistochemistry. Samples were collected during periapical surgery, of which 15 were used for Real-Time RT PCR (8 periapical granulomas, 6 periapical cysts and 1 apical scar), and 20 for immunehistochemistry (10 periapical granulomas). The results for Real-Time PCR showed MMP-2, -9, -14, TIMP-1, -2, and RECK expression in periapical granulomas and cysts, with no significant statistical differences between the two periapical pathologies regarding the genes tested. However, when the group periapical lesion (granuloma and cyst) was confronted with the genes tested, there was a significant correlation in some mRNA expression for MMP-2, -9, 14, TIMP-1, -2 and RECK. Regarding immunostainings in the periapical granulomas, MMP-2 was more diffusely expressed, being located peripherally to the cells and dispersed through the ECM, when compared to MMP-9 which presented a more localized and restrained pattern. Macrophages were the most abundant cells expressing these MMPs. 


\section{Universidade de São Paulo \\ Faculdade de Odontologia de Bauru}

Al. Dr. Octávio Pinheiro Brisolla, 9-75 - Bauru-SP - CEP 17012-901 - C.P. 73

PABX (0XX14)3235-8000 - FAX (0XX14)3223-4679

Comitê de Ética em Pesquisa (3235-8356)

Processo $n^{\circ} 43 / 2005$

Bauru, 05 de outubro de 2005.

Senhor Professor,

Informamos que após o envio da documentação solicitada referente ao projeto de pesquisa encaminhado a este Comitê de Ética em Pesquisa "Análise da expressão de matriz metalloproteinase-2 (MMP-2), -9 e RECK (Reversão induzida por proteína rica em cisteina com kazal Motifs) e granulomas e cistos periapicais)" de autoria de Everdan Carneiro que será desenvolvido sob sua orientação, foi novamente analisado e considerado APROVADO por este Comitê nesta data.

Informamos ainda, que após o envio do trabalho concluido, este Comitê enviará o parecer final, que será utilizado para publicação do trabalho.

Atenciosamente,

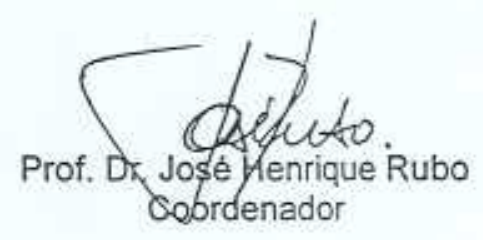

$\| m^{\circ} \mathrm{Sr}$. Prof. Dr. Roberto Brandăo Garcia

DD. Docente do Departamento de Dentistica, endodontia e Materiais Dentários 